\title{
A SYNOPSIS OF THE SPECIES OF AFRICAN CULICIDAE, OTHER THAN ANOPHELES.
}

\author{
By F. W. Edwards, B.A., F.E.S.

\section{(Published by permission of the Trustees of the British Museum.)}

Little is needed by way of introduction, beyond the statement that this paper is really a continuation of a previous one "The African Species of Culex and allied Genera," Bull. Ent. Res., Oct. 1911, pp. 241-268). In the present paper a complete synopsis is given of all the African species, with the exception of some of those already tabulated and of the genus Anopheles and its sub-divisions. Through the kindness of Prof. R. Newstead, the author has now been able to examine the types in the collection of the Liverpool School of Tropical Medicine, so that the number of undetermined species has been considerably reduced, and all have now been accounted for except those given as doubtful in the paper referred to.

The classification of Lt.-Col. A. Alcock has been adhered to, except that Dixa has been admitted, forming a third sub-family. In this the writer is following the expressed opinion of Prof. S. W. Williston. The names adopted for the tribes of the Culicinas are those used by Messrs. Dyar and Knab, while, in agreement with Lt.-Col. Alcock, the Megarhinin i have been retained as a distinct tribe. So far as possible, full generic synonymy has been given, but synonyms of the species, unless determined by the author, have as a rule been omitted.

It must not be supposed that anything like finality is claimed for the conclusions expressed here. Many questions require considerably more study, while others must apparently always be matters of personal opinion. The examination of more material has necessitated the partial modification of views previously given, while some errors in the author's previous paper on the subject have come to light and are here corrected. Doubtless some still remain.

Mr. H. F. Carter has very kindly lent me a paper published by G. F. Leicester in 1908, which he had unearthed. This has apparently been completely overlooked; it contains descriptions of a large number of species and genera, some of which are referred to later in this paper.

\section{Sub-family 1. CULICINAE.}

Proboscis elongated; palpi frequently elongated in one or both sexes, but straight when short; wings and legs scaly, and except in some species of Anopheles, the thorax and abdomen also.

This sub-family includes all the true mosquitos, and is co-extensive with the family CulicidaE as defined by Theobald and others. Although the proboscis is always elongate (usually about the length of the abdomen), it must not be upposed that all the species are blood-suckers-the structure of the proboscis indeed is sometimes such as to exclude the possibility of the blood-sucking habit 
being developed, while other species which probably could suck blood do not do so ; others only do it occasionally, and the males never. Many feed on plantjuices in the adult stage, while one genus (Harpagomyia) is myrmecophilous.

The known species of this sub-family are far more numerous than those of the other two together, and they fall into three or four fairly well-marked tribes. Some authors go much further than this and divide the mosquitos into ten or eleven sub-families, while it has even been proposed to raise one genus (Anopheles) to family rank. The tendency seems to be for the group which would formerly (say fifteen years ago) have been regarded as a genus, to become a sub-family, while the species become genera, and varieties-individuals almostspecies. The present writer follows Lt.-Col. A. Alcock in recognising four tribes of the sub-family Culicinat. For these it seems better to retain the names of the oldest genera rather than to coin new terms, and hence these tribes are here spoken of as-

\section{Anophelini. \\ 2. Megarhinini. \\ 3. Culicini. \\ 4. Sabethini.}

The great majority of the species belong to the CuLicini, the other three tribes being represented each by a single genus in the African region. The first of these tribes is not dealt with in the present paper.

\section{Tribe Megarhinini.}

Proboscis with the apical half much thinner than the basal, and bent downwards at an angle with it. Scutellum evenly rounded. Wings long and narrow; fork-cells both very short, but the first much shorter than the second. Wingmargin indented just before the termination of the posterior branch of the fifth longitudinal vein, and with a small $V$-shaped thickening of the membrane opposite this indentation. Large species, completely clothed with flat, more or less metallic scales, usually blue or green. Larvae predaceous; adults not bloodsuckers.

Dyar and Knab place these insects in the Culcini, and consider them to be relaied to Psorophora and its allies. Both groups agree in having predaceous larvae, and in the head of the imago being provided with a distinct neck, but these characters are very likely not indicative of relationship, and so it is considered better to treat Megarhinus and Toxorhynchites as forming a separate group. The predaceous habit of the larvae, with its corresponding modifications of structure, has been developed several times independently.

Genus Toxorhynchites, Theo.

Mon. Cul. I, p. 244 (1901).

Worcesteria, Banks, Philipp. J. Sci. I, p. 779 (1906).

Teromyia, Leicester, Stud. Inst. Med. Res., Fed. Malay States, III, p. 49 (1908).

The name of this genus was first published by Dr. L. O. Howard in 1901 ("Mosquitoes," pp. 154, 155, 235, 240), who figured the North American 
Megarhinus rutilus as Toxorhynchites rutilus, making his figure from a female which happened to have the palpi broken. Accordingly some have said that M. rutilus must be taken as the type of the genus Toxorhynchites, which in that case becomes a synonym of Megarhinus. But (1) Howard expressly stateả that he had borrowed the name from proof-sheets of Theobald's monograph; (2) he said nothing to indicate that he wished to regard $\boldsymbol{M}$. rutilus as the type species, while Theobald named $T$. brevipalpis as the type; (3) although he included Toxorhynchites in a table of genera he gave no detailed description of it. Theobald's monograph was published in November, 1901.

\section{Table of Species.}

1. Abdomen shining orange ; third hind tarsal joint white at base*; claspers of genitalia with a long terminal spine

1. lutescens. Abdomen metallic blue or violet; second hind tarsal joint* broadly white

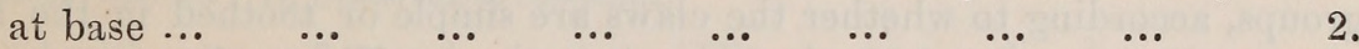

2. Abdomen mostly blue; second tarsal joint of middle legs, sometimes also

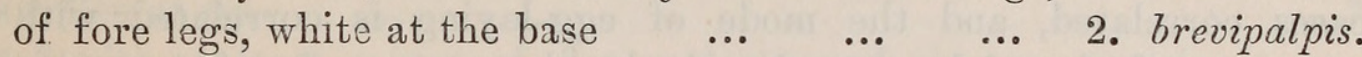
Abdomen violet; second and third tarsal joints of mid legs entirely $\begin{array}{lllllllll}\text { white } & \ldots & \ldots & \ldots & \ldots & \ldots & \ldots & \ldots & 3 . \\ \end{array}$

1. T. lutescens, Theo. (Megarhinus), Mon. Cul. I, p. 233 (1901).

Known only from a single male.

S. Rhodesia.

2. T. brevipalpis, Theo., Mon. Cul. I, p. 245 (1901).

Toxorhynchites marshalli, Theo., Mon. Cul. III, p. 121 (1903).

Toxorhynchites conradti, Grünb., D. ent. Zs. p. 405 (1907).

The metatarsi usually have a narrow white ring at the base, but both this and the broad ring on the second tarsal joint are sometimes incomplete dorsally. Usually the front tarsi are entirely dark, but there is sometimes a white ring on the second joint.

Sierra Leone; Ashanti; N. and S. Nigeria: N. Kamerun; Congo; Uganda; British Central Africa; S. Rhodesia; Natal.

3. T. phytophagus, Theo. (phytophygus), Mon. Cul. V, p. 102 (1910). Ashanti.

\section{Tribe Culicini.}

Thorax more or less rounded ; metanotum without bristles; scutellum more or less distinctly trilobed. Larvae with air-tube and median ventral brush on anal segment (after the first stage).

This tribe includes the old genera Culex and Aëdes, which were defined as having long and short palpi respectively in the male. Most authors have used this character for the primary division of the group, a division which was adopted by the writer (Bull. Ent. Res. Oct. 1911, p. 242). Messrs. Dyar and Knab, however, owing to their exhaustive study of the larval characters of the North 
American species, arrived at the conclusion that the length of the palpi is only of minor importance, and that long (or, as they consider, short) male palpi have been developed independently in different groups. After examining all the material in the British Museum in the light of these views-which I much regret I had not done before publishing any synoptic work-I feel bound to agree with the American authors. They, however, go further, and refuse to recognise even generic value in the differences of the palpi, since in most cases these are confined to one sex. Although there is a great deal to be said for this view, it has not been followed in the present paper, and hence it should be remembered that some groups which are here given generic rank, would by some authors be regarded only as subgenera, even if recognised at all. Scale characters have practically been discarded as of value for generic definition, though it is true that groups of species frequently show the same type of ornamentation in all their members.

Coquillett (Science, xxiii, p. 312, 1906) divided the old genus Culex into two groups, according to whether the claws are simple or toothed in the female, and whether the eggs are laid singly or in masses. These characters are in most cases correlated, and the mode of egg-laying is correlated with a definite structure of the abdomen. No doubt there are a few forms which would be difficult to place, but by far the larger number of Culicini fall into one of two groups, which seem to be quite natural :-

(1.) Aëdes group. Eggs laid singly ; last segment of female abdomen narrow, usually completely retractile into the penultimate; claws of female, at least on the four anterior legs, nearly always toothed. Genera: Mucidus, Psorophora, Janthinosoma, Ochlerotatus, Stegomyia, Aëdes, etc.

(2.) Culex group. Eggs laid in masses ; last segment of female abdomen broad, immovable; claws of female never toothed. Genera: Culex, Taeniorhynchus, Aëdomyia, Theobaldia, Uranotaenia, etc.

This division of the tribe is much more natural than one based on the length of the palpi; it will be seen that forms with short male palpi are included in both groups.

\section{Table of Genera.}

1. Claws of female toothed Claws of female simple

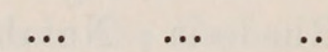

$\begin{array}{lll}\cdots & \cdots & \cdots\end{array}$

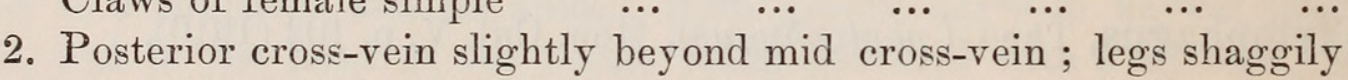
scaled; female palpi half as long as proboscis ... Mucrdus, p. 6.

Posterior cross-vein before mid cross-vein; legs not shaggily scaled, female palpi not half as long as proboscis

3. Male palpi with two apparent joints ; thorax bright yellow at the

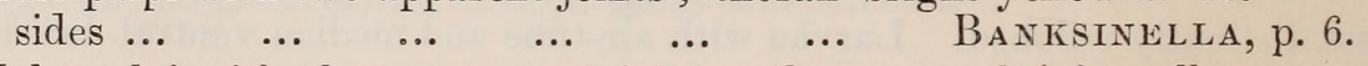

Male palpi with three apparent joints; thorax not bright yellow $\begin{array}{lllllllll}\text { at } \text { sides } & \ldots & \ldots & \ldots & \ldots & \ldots & \ldots & \ldots & \ldots\end{array}$

4. Last two joints of male palpi thin, about equal in length; black and white species; head all flat-scaled ... $\quad .$. Stégomy ia, p. 7.

Last two joints of male palpi more or less thickened, especially the penultimate, which is longer than the terminal; not usually black and white species, head not usually flat-scaled above

Ochlerotatus, p. 14. 
5. Eighth segment of female abdomen slender, retractile; male re-

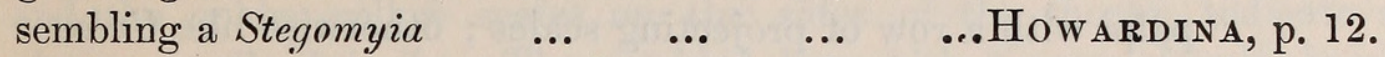
Eighth segment of female abdomen broad, truncate (except in

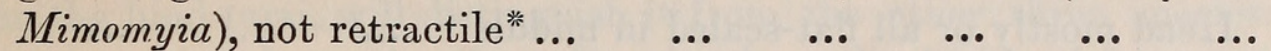

A

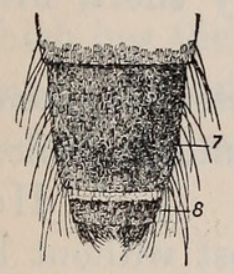

B

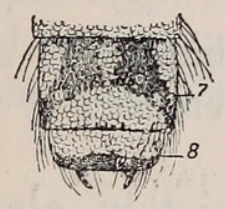

$\mathrm{C}$

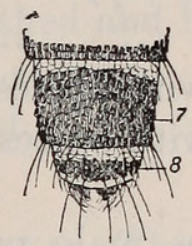

D

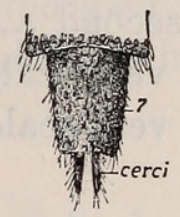

Fig. 1.-Terminal segments of female abdomen (dorsal view) :-A, Culex tigripes var. fuscus, a specimen with distended abdomen; B, Culex tigripes, abdomen not distended; C, Mimomyia hispida ; D, Ochlerotatus cumminsi.

6. Head without any flat scales in the middle above; proboscis never swollen at tip

Head with at least a row of flat scales round the eye-margins, usually almost entirely clothed with flat scales; proboscis often swollen at tip

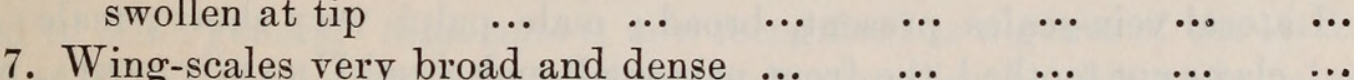

Wing-scales not very broad (in African species-but cf. $\begin{array}{lllllllll}\text { Culex ager }) & \ldots & \ldots & \ldots & \ldots & \ldots & \ldots & \ldots & \ldots\end{array}$

6. .

Male palpi as long as proboscis, thin, last joint very short

Mansonioides, p. 24.

Palpi similar in both sexes, very short; middle femora with a tuft

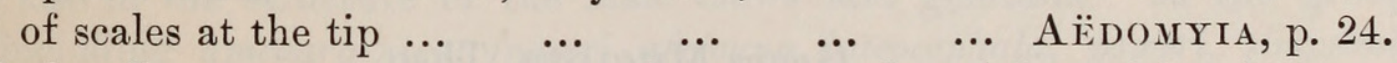

9. Fork-cells very short; wings nearly bare; male palpi two-jointed

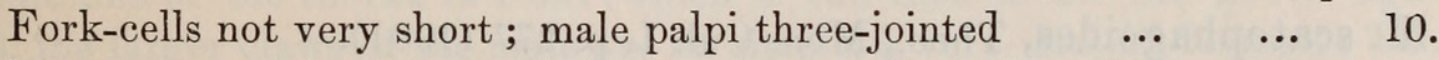

10. Metatarsus of hind legs distinctly shorter than the tibia; male

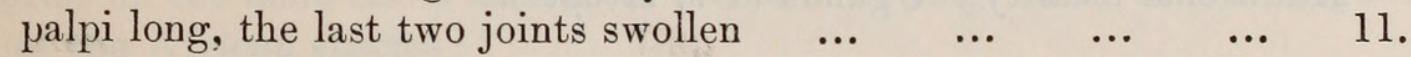

Metatarsus of hind legs at least as long as the tibiat (usually longer) ; male palpi thin (long or rather long) $\quad \ldots \quad \ldots \quad \ldots$

11. Penultimate juint of male palpi thicker and somewhat longer than terminal one; usually yellow species ... TAeniorhynchus, p. 25.

Penultimate joint of male palpi thinner but not longer than terminal one; not yellow species; cross-veins almost in a line

Theobaldia, p. 27.

12. Male palpi longer than proboscis, last two joints curved upwards

Culex, p. 27.

Male palpi shorter than proboscis, straight...PROTOMELANOCONion, p. 33.

* Taeniorhynchus has this segment rather small and narrow, but not at all retractile; while Mansonioides exhibits a very peculiar structure of the female abdomen : the eighth segment is permanently retracted within the seventh, which is very short, being not longer than the eighth segment of Culex; there are two very large and broad cerci, which, however, are not prominent like those of Ochlerotatus.

+ Culex argenteopunctatus is an exception to this, as it has the hind tibia slightly longer than the metatarsus. 
13. A row of small flat scales round the eyes; basal joint of male palpi with a row of projecting scales; otherwise like Culex

Culiciomyia, p. 33.

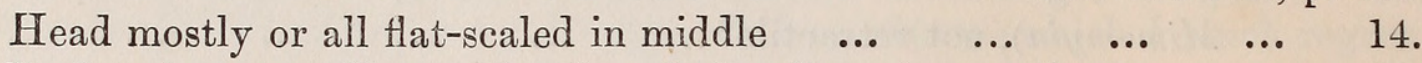

14. Proboscis not swollen at the tip ; fork-cells not very short $\ldots . .15$.

Proboscis swollen at tip, or fork - cells very short, first shorter $\begin{array}{lllllllll}\text { than second } \ldots & \ldots & \ldots & \ldots & \ldots & \ldots & \ldots & \ldots & 17 .\end{array}$

15. Lateral vein-scales with apices simple; 0 antennae plumose $\quad . \quad 16$. Lateral vein-scales with apices dentate; 0 antennae pilose

Hodgesia, p. 35.

16. Medium-sized species, male palpi thin, almost without hairs, and slightly shorter than the proboscis _.. Eumelanomyia, p. 34.

Very small species, male palpi short like those of the female

MicraËDEs, p. 34.

17. Fork-cells very short, first shorter than second $\quad \ldots \quad \ldots \quad \ldots l$.

$\begin{array}{lllll}\text { Fork-cells not very short, first not shorter than second } & \ldots & \ldots & 19 .\end{array}$

18. Lateral vein-scales absent; male palpi long, two-jointed, apical one swollen; fore and mid claws of male unequal, toothed

Mimomyia, p. 35.

Lateral vein-scales present, broad; male palpi very short; male claws not toothed, the front pair small and equal URANOTAENIA, p. 37.

19. Proboscis not hairy; male palpi thin, about two thirds as long as proboscis; silvery markings absent _.. IngRamia, gen. n., p. 43.

Proboscis bearing long hairs; male palpi short; clypeus rather long and narrow ; silvery markings on pleurae and abdomen

HARPAGOMYIA, p. 45.

Genus Mucidus, Theo.

Mon. Cul. I, p. 268 (1901).

M. scatophagoides, Theo., Mon. Cul. I, p. 277 (1901).

Additional locality : Uganda (Dr. Hodges).

Genus Banksinella, Theo.

Mon. Cul. IV, p. 468 (1907).

B. luteolateralis, Theo., Mon. Cul. II, p. 71 (1901).

Newstead's Neomelanoconion palpale (Ann. Trop. Med. I, p. 31, 1907) is referable to this species, as has been proved by an examination of the type $\left(O^{*}\right)$.

A single male bred by Dr. A. Ingram may represent a new species allied to $B$. luteolateralis, but it cannot be described without more material. In this specimen the neuration is almost exactly as in Mimomyia, and there are very few lateral scales on the veins; the thin palpi and shorter and less plumose antennae and general appearance, however, show it to be a Banksinella. The thorax is uniformly clothed with golden scales.

On re-reading the description of Taeniorhynchus africanus, Neveu-Lemaire (Arch. Parasit. X, p. 271, 1906), I am inclined to think it is a Banksinella. The female only has been described, so it is not possible to say definitely, but the 
golden-yellow scales in the middle of the head, produced in front as a tuft of "hairs," and the golden-yellow scales on the sides of the thorax, indicate a possible relation to Banksinella. The marbled legs with traces of pale basal banding on the hind tarsi, will distinguish it from the other three species. The species was recorded from the Suez Canal; the only Aëdine I have seen from there which at all corresponds to the description of T. africanus is Ochlerotatus dorsalis, Mg., which has the hind claws toothed and has speckled wings, the latter character not being mentioned by Neveu-Lemaire. O. dorsalis has several times been taken on board ship in the Suez Canal.

\section{Genus Steqomyia, Theo.}

Mon. Cul. I, p. 283 (1901).

Armigeres, Theo., Mon. Cul. I, p. 322 (1901).

Desvoidya, Blanchard, Les Moustiques, p. 265 (1905).

Gymnometopa, Coquillet, Proc. Ent. Soc. Wash. VII, p. 183 (1906).

Kingia, Theo., Mon. Cul. V, p. 135 (1910).

This genus was founded upon the world-wide S. fasciata, F., with which has been included a number of other species; most of these have since been transferred to other genera. Stegomyia is now recognised as a genus of the Aëdes group allied to Ochlerotatus, but differing from that genus in the thin male palpi. The eighth abdominal tergite in the female is larger than in normal Ochlerotatus, and not completely retractile; while the female genital appendages (cerci) are usually rudimentary, though quite well developed in S. simpsoni; in Ochlerotatus they are nearly always well developed. The genus Stegomyia shows considerable variation also in the structure of the male claws and genitalia. In the group Kingia (including apicoargentea, fraseri, africana, luteocephala, poweri, simpsoni, metallica and pseudonigeria), characterised by Theobald as having flat scales in the middle line of the thorax in front (which is the case in all the above eight species), the larger claws of the male are all simple, a very unusual feature. The various forms of the male claws are shown in the following table of the ungual formulae of the African species : *
S. simpsoni
S. metallica
S. africana
S. apicoargentea
$\begin{array}{llll}\ldots & 0.0 . & 0.0 . & 0.0\end{array}$
S. luteocephala
S. fasciata...
\}
O.1. O.1. 0.0 .
S. sugens ...
... O.1. O.1. 1.1.
... I.0. O.0. 0.0 .
... I.1. I.1. 0.0 .

The males of the other species are unknown. $S$. (Desvoidya) obturbans has claws of similar structure to those of S. sugens, and has very peculiar genitalia.

The type species of Gymnometopa ( $G$. mediovittata, Coq., not, as Theobald states, G. sexlineata, Theo.) has toothed claws in the female, so that this genus becomes a synonym of Stegomyia rather than of Howardina.

- Some of these formulae differ from those given by Theobald, but I can vouch for their correctness, and have not come across any variations. 
If the genus as now defined is dismembered, it may be found necessary to restrict it to the type species, $S$. fasciata, which has a very peculiar character in the scaly clypeus. However, the line taken by Dyar and Knab of sinking both Stegomyia and Ochlerotatus under Aëdes would be wiser, probably, than further subdivision. A middle course has been adopted here.

The specific characters which are most readily appreciated are found in the markings of the hind tarsi, and these have been used for purposes of tabulation. Other characters of diagnostic value are given under each species. All the species are black with white or silvery markings.

\section{Table of the Species.}

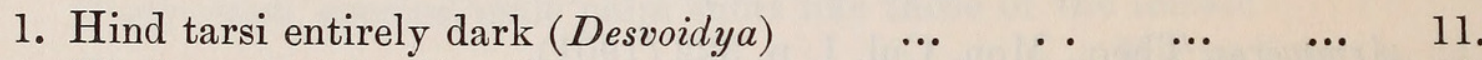

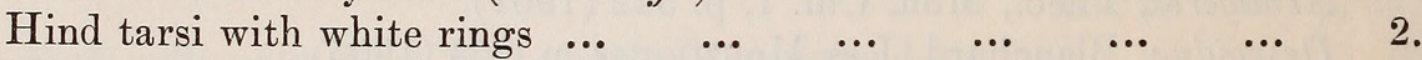

2. Rings on first four joints of hind tarsi almost equal in length, last joint usually all white (compare Ochlerotatus fascipalpis, which

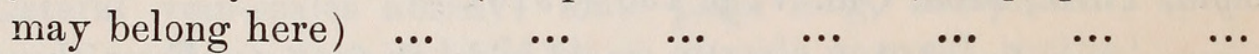

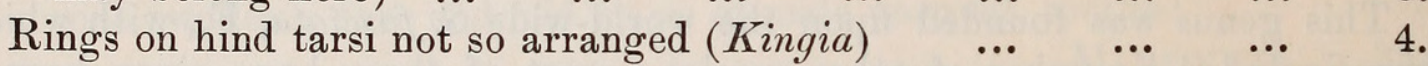

3. Clypeus scaly; thorax with lyre-shaped white marks (Stego-

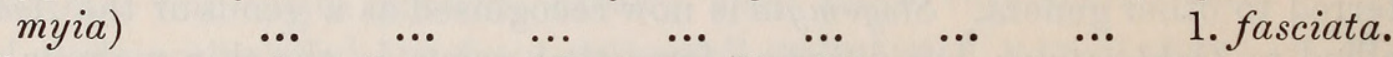

Clypeus not scaly; thorax with six small white spots $\quad . .2$ 2. sugens.

4. Last two joints of hind tarsi all white ; middle femora practically

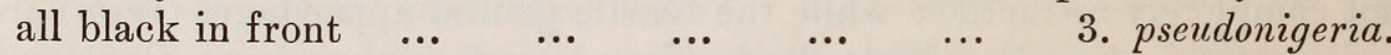

Last two joints of hind tarsi not all white; middle femora with a conspicuous white or silvery spot near the middle in front $\quad \ldots \quad 5$.

5. White ring on third joint of hind tarsi much broader and more con-

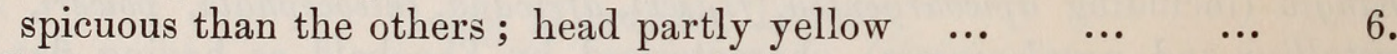

White ring on third joint not very broad, though that on the fourth may be ; head not at all yellow $\quad \begin{array}{llllll} & \ldots & \ldots & \ldots & \ldots & \ldots\end{array}$

6. Hind tibiae with a large white patch at the base beneath; headscales mostly black, leaving a small yellow patch in the middle

Hind tibiae with a very small yellow patch at the base beneath; head-scales mostly deep yellow $\quad \ldots \quad \ldots \quad \ldots \quad \ldots \quad$ 5. luteocephala.

7. Fourth joint of hind tarsi mostly or all white $\quad \ldots \quad \ldots . \quad \ldots \quad 8$.

Fourth joint of hind tarsi mostly or all black; fifth, mostly or all white; all segments of abdomen with broad white bands $\quad . . \quad 10$.

8. Thorax with a thin median yellow line; abdomen with all seg$\begin{array}{llllllll}\text { ments banded } \quad \ldots & \ldots & \ldots & \ldots & \ldots & \ldots & 6 \text {. poweri. }\end{array}$

Thorax without such line, abdomen with segments $1-3$ or $1-4$ $\begin{array}{lllllllll}\text { unbanded } \quad \ldots & \ldots & \ldots & \ldots & \ldots & \ldots & \ldots & \ldots\end{array}$

9. Lateral lobes of scutellum with black scales, last joint of hind tarsi $\begin{array}{lllllll}\text { almost all black } \quad \ldots & \ldots & \ldots & \ldots & \ldots & 7 \text {. apicoargentea. }\end{array}$

Lateral lobes of scutellum with white scales, last joint of hind tarsi

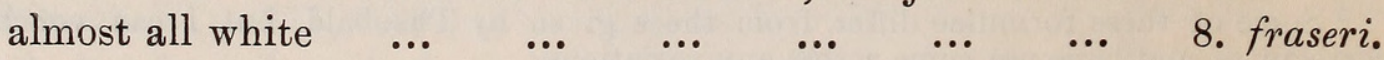


10. A line of more or less narrow, curved, white scales on either side of the bare space in front of the scutellum $\quad \ldots \quad \ldots .9$. simpsoni.

A patch of broad flat silvery scales in this position $\quad . .10$. metallica.

11. Head with a median patch of flat white scales behind; disc of thorax with light bronzy-brown scales $\quad \ldots \quad \quad \ldots \quad 11$. albomarginata.

Head with a white border only; disc of thorax with bronzy-black

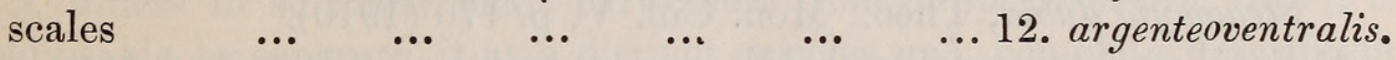

1. S. fasciata, F. (Culex), Syst. Antliatorum, p. 13 (1805).

Culex calopus, Meigen, Syst. Bes. I, p. 3 (1818).

Stegomyia nigeria, Theo., Mon. Cul. I, p. 303 (1901).

The type of S. nigeria is in very bad condition, but there is quite enough of it left to show that it is the unmistakable $S$. fasciata. It was described from a single specimen. In the fifth volume of his Monograph, Theobald records a specimen of S. nigeria from Bailundu, Angola : this on examination proves to be a typical, if somewhat rubbed, specimen of $S$. pseudonigeria.

The legs of $S$. fasciata distinguish it from all the other species, as the femora all have a narrow white line running almost their entire length. The abdomen is usuaily black, with basal and often also apical whitish bands on all the segments ; in one desert variety, however, the general hue is light brown instead of black.

S. fasciata is common throughout the warmer parts of the world. From the fact that a number of African species are rather nearly related to it, a guess may be hazarded that its original home was in this region.

2. S. sugens, Wied., Aus. Zweifl. Ins. I, p. 545 (1828).

Scutomyia sugens, Theo., Gen. Ins., Culicidae, p. 19 (1905).

Stegomyia brumpti, Neveu-Lemaire, Bull. Soc. Zool. France, XXX, p. 8 (1905).

Reedomyia albopunctata, Theo., Mon. Cul. IV, p. 262 (1907).

Dr. Neveu-Lemaire gives such good figures and description of his species (Arch. Parasit. X, 1906, pp. 261-265) as to leave no doubt that it is the same as $S$. sugens, Wied., as interpreted by Theobald. He finds that the hind claws of the male may be toothed or not, or one toothed and the other not. The types of $R$, albopunctata are in poor condition, but quite recognisable.

The species can be easily recognised by the six white spots on the thorax, and also by the white bands near the apices of the femora and near the bases of the tibiae.

Sudan; Abyssinia; Uganda; Gambia; N. \& S. Nigeria; Sierra Leone; Gold Coast; Angola ; S. Rhodesia; Transvaal ; Aden ; India ; Corsica.

3. S. pseudonigeria, Theo., Mon. Cul. V, p. 166 (1910).

S. wellmani, Theo., Mon. Cul. V, 163 (1910).

The name psendonigeria is used for this species, because Danielsia wellmani, Theo. (1905), known only from the female, may be a Stegomyia and not an Ochlerotatus. In any case it would be well not to duplicate specific names in the Aëdes group. 
This species is easily recognisable by the characters given in the table, but it is closely related to $S$. poweri, the markings of the thorax and abdomen being almost identical.

Angola.

4. S. africana, Theo., Mon. Cul. I, p. 304 (1901).

Stegomyia dubia, Theo., Mon. Cul. V, p. 170 (1910).

S. dubia was, to use Theobald's own expression, "described from a worn and damaged female," but there is no visible character by which to separate it from S. africana.

Hind femora in front with a large silvery spot about the middle, a small one close to the apex. Thorax with large oblong silvery lateral patches, and a fine yellowish median line, not always visible. Abdomen without distinct bands, but with lateral white spots, extended towards the mid-dorsal line in the middle of each segment; those on the seventh segment visible dorsally. Scales on pleurae silvery.

Sierra Leone ; N. \& S. Nigeria ; Congo ; Uganda ; Angola ; N. E. Rhodesia.

5. S. Iuteocephala, Newstead, Ann. Trop. Med. 1, p. 15 (1907).

Kingia luteocephala, Theo., Mon. Cul. V, p. 136 (1910).

This species must be taken as the type of the Theobaldian genus Kingia, which, if retained, would include all the African Stegomyia except $S$. fasciata, S. sugens, S. albomarginata, and S. argenteoventralis.

Very much like $S$. africana. A yellow patch on each side of the thorax above and in front of the roots of the wings. Scales on pleurae pale golden. Abdomen with narrow dull yellowish basal bands. Hind claws toothed.

Sudan; Uganda; S. Nigeria; Congo.

\section{S. poweri, Theo., J. Econ. Biol. I, p. 18 (1905).}

Thorax with a fine median yellowish line, becoming broad and silvery in front; with the usual two lateral silvery-white spots. Abdominal segments 2-6 with dull white basal bands. Hind femora with the basal half white. Hind tibiae broadly white at the base beneath.

Very close to $S$. pseudonigeria, but easily distinguished by the white spot on the mid femora, and the black fifth joint of the hind tarsi.

Congo; British East Africa; N. E. Rhodesia; Bechuanaland; Natal.

7. S. apicoargentea, Theo., Mon. Cul. V, p. 17£ (1910).

Thorax with two large roundish silvery-white spots, and two smaller ones just in front of the bases of the wings. Median lobe of scutellum with silvery white scales, lateral lobes with black ones. Scales bordering the bare space in front of the scutellum black. Segments 1-4 of abdomen with the lateral patches large, white; on 5-7 they are smaller, silvery; segments 5-8 (sometimes 4-8) with median basal silvery patches. Fore and mid femora with a silvery white line beneath, especially marked near the apex of the fore femora; mid femora silvery at the apex in front; hind femora in front with the basal half and also the apex silvery; behind they are all black, except at the base where they are yellowish. Hind tibiae with a white mark on the outside about one-third of the 
way from the base, scarcely any white at the base beneath. Fifth joint of hind tarsi practically all black.

Ashanti ; Sierra Leone; S. Nigeria ; Uganda.

8. S. fraseri, sp. n. $Q$.

One female from Mpumu Forest, Uganda, July, 1910 (Capt. A. D. Fraser, R.A.M.C.), differs in so many small particulars from $S$. apicoargentea, that it is thought advisable to separate it as a distinct species. A complete description does not seem necessary, but so far as observable all the points of difference between it and the preceding are given :

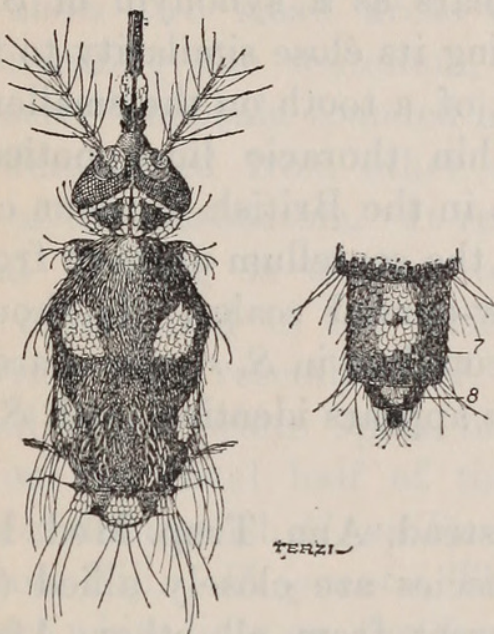

Fig. 2.-Stegomyia fraseri, sp. n. Head and thorax, and apex of abdomen (우).

Scutellum with the lateral lobes entirely clothed with silvery white scales and a similar large central patch on the median lobe. Scales bordering the bare space in front of the scutellum yellowish. Mid and hind femora in front with the apex white, without any silvery metallic lustre. 'Basal half of hind femora silvery white in front, basal two-fifths yellowish white behind. Hind tibiae with a white mark as in $S$. apicoargentea, but in this species it is connected with a large yellowish patch at the base beneath. Last joint of hind tarsi almost all white.

Several of the above characters show that this species is more or less intermediate between $S$. apicoargentea, $S$. poweri and S. pseudonigeria, being at once distinguished from the last two by the abdominal markings, and the shape of the spots on the thorax.

Type in the British Museum.

9. S. simpsoni, Theo., Entomologist, XXXIX, p. 224 (1905).*

Stegomyia lilii, Theo., Mon. Cul. V, p. 160 (1910).

Stegomyia bromeliae, Theo., Novae Culicidae, 1, p. 10 (1911).

A line of white scales on each side of the bare space in front of the scutellum, usually continued as two very fine lines of yellow scales across to the front of the

* Since writing the abore notes, I have found that the female claws of this species are variable. I had inadvertently overlooked Theobald's statement that the claws of S. simpsoni are all simple, but an examination proved this to be quite correct as regards two Transvaal specimens. Some others, however, from Abyssinia, though otherwise indistinguishable from the type of S. simpsoni, have toothed claws. This of course invalidates the genus Howardina, which must in consequence sink under Stegomyia. 
mesonotum, but these lines are sometimes indistinct anteriorly or even absent altogether (especially in the male). The female cerci are longer in this than in any other species of the genus, equalling the eighth abdominal tergite in length. I can see nothing to separate $S$. lilii or $S$. bromeliae from $S$. simpsoni, beyond the absence of the yellow lines on the thorax.

Sudan; Abyssinia ; Uganda ; Nyasaland ; Transvaal ; Angola.

\section{S. metallica. nom. n.}

Quasistegomyia dubia, Theo., Mon. Cul. V, p. 133 (1910).

The new name is proposed to avoid confusion with Stegomyia dubia, Theo., which, however, also disappears as a synonym of $S$. africana. The species is probably valid, notwithstanding its close similarity to the preceding, owing to the presence, already referred to, of a tooth on the smaller claw of the fore and mid feet of the male. The thin thoracic lines noticed in S. simpsoni are not observable in the single male in the British Museum collection. The patches of flat silvery scales in front of the scutellum unite in front of the bare space into a small patch of white narrow-curved scales. It should be mentioned that the white scales in front of the scutellum in S. simpsoni are variable in width. Apart from these points $S$. metallica appears identical with $S$. simpsoni.

Sudan.

\section{S. albomarginata, Newstead, Ann. Trop. Med. I, p. 16 (1907).}

This and the following species are closely allied (possibly local races of one species), but strikingly different from all other African species in markings. They approach closely to the Oriental Desvoidya obturbans, and though the males of the African species are unknown there is no doubt that they belong to the Desvoidya group of Stegomyia.

This species was described by Newstead from one female, with the fifth and following segments of the abdomen missing. It differs from the next species, apart from the characters mentioned in the table, in having very few white scales on the front of the mesonotum.

Congo.

12. S. argenteoventralis, Theo. (Dendromyia), Mon. Cul. V, p. 588 (1910).

Dendromyia affinis, Theo., Mon. Cul. V, p. 589 (1910).

As stated elsewhere this species has no bristles on the metanotum and bears no relation to the SABEтHini. There is a rather large white area on the front of the mesonotum. This species, with S. albomarginata, differs from all other African CULICIDAE in having the front and under surface of the hind femora entirely white. The venter is also strikingly white, except the last two segments, which are black. In $D$. obturbans the femora are marked in the same way, but the venter sometimes (not always) shows apical dark bands.

Ashanti.

$$
\begin{aligned}
& \text { Genus Howardina, Theo. } \\
& \text { Mon. Cul. III, p. } 287 \text { (1903). }
\end{aligned}
$$

? Macleaya, Theo., Entomologist, XXX VI, p. 154 (1903).

Scutomyia, Theo., Entomologist, XXX VII, p. 77 (1904).

Quasistegomyia, Theo., Second Rept. Wellc. Lab., p. 69 (1906).

This genus differs from Stegomyia in that the claws of the female are all simple. Messrs. Dyar and Knab include Haemagogus, and say of the genus, "We take 
this to be a group specialised off from Aëdes, the tarsal claws of the female having lost the tooth. The small end joint of the [female] palpus is retained, which differentiates the genus from Culex." Haemagogus differs in having the prothoracic lobes large and approximated.

1. H. unilineata, Theo. (Quasistegomyia), Second Rept. Wellc. Lab, p. 70 (1906).

Stegomyia gebeleinensis, Theo., Mon. Cul. V, p. 157 (1910).

" gelebeinensis, Theo. (error), Mon. Cul. V, p. 151 (1910).

Both the types are very much broken, but the thorax of each remains in fairly good preservation. Both show two small areas of black flat scales on the mesonotum immediately preceding the scutellum, which is clothed with flat white scales. On this character Theobald founded his genus Quasistegomyia.

H. unilineata is easily differentiated from other African CULICIDAE by the white line down the middle of the mesonotum. It resembles Stegomyia in general appearance, and the tarsal banding is similar to that of $S$. fasciata and S. sugens. The species is represented in the Oriental Region by the common $H$. ("Stegomyia") scutellaris. This resembles $H$. unilineata in most respects, but lacks the pair of small round white spots on the posterior half of the mesonotum and the spots on the distal half of the front of the mid femora. These two characters will also distinguish $H$. unilineata from $H$. pseudoscutellaris, Theo., recently described from Fiji. H. grantii, Theo., from Sokotra, is not so closely allied. It has distinct white lines on the femora and tibiae, and different thoracic marking's.

Sudan; N. Nigeria (Baro, 2 Q, Dr. Ingram); British E. Africa (Dolo, 1 , Dr. R. E. Drake-Brockman).

2. H. (?) pembaensis, Theo. (Aëdes), Mon. Cul. II, p. 235 (1901).

Verrallina pembaensis, Theo., Mon. Cul. V, p. 495 (1910).

This was described from a single female in bad condition, and must remain of doubtful position until more material can be obtained. The eighth segment of the abdomen seems to be broken off, so that I am not quite sure that it belongs to the Aëdes group. What scales are left on the head are flat, and, except for a row round the eye-margins, black. The thoracic scales seem to have been blackish, from the few that are left, and there are a few flat white scales on the scutellum. Abdomen blackish, with smell basal lateral white spots. Legs brownish, unbanded.

Pemba Island.

3. H. (?) lineata, Theo. (Pseudohowardina), Entomologist, XLV, p. 92 (1912).

" $\sigma$ and $O$. Head deep brown, with a median white line and a thin white line around the eyes; proboscis deep brown, with a line of white scales on the basal half. Thorax deep brown, with three thin pale yellow lines, the median one forked around the bare space in front of the scutellum, a thin white line on each side; two broken white lines on the pleurae and spots. Abdomen deep brown, with traces of apical white bands and apical spots. Legs deep brown, unbanded, femora with a white line beneath, and in certain lights the tibiae pale yellow. Male palpi acuminate, no hair tufts, brown. Length, @ 3.5-4.5, ठ 4 mm." 
Described by Mr. Theobald from a male and three females from the Transvaal (Onderstepoort). As he does not mention the structure of the female claws and abdomen I am not certain that it is correctly placed here. There is a single male in the British Museum collection from Natal (Ulundi, 5,000-6,000 ft., September, 1896, G. A. K. Marshall). There is no other African species at all resembling this.

\section{Genus Ochlerotatus, A rrib.}

Rev. Mus. La Plata II, p. 143 (1891).

? Gilesia, Theo., Mon. Cul. III, p. 233 (1903).

Acartomyia, Theo., Mon. Cul. III, p. 251 (1903).

Finlaya, Theo., Mon. Cui. III, p. 281 (1903).

Aedimorphus, Theo., Mon. Cul. III, p. 290 (1903).

Culicelsa, Felt, N.Y. State Mus. Bull., p. 391 b (1901).

Culicada, Felt, l.c.

Ecculex, Felt, l.c.

Protoculex, Felt, I.c.

? Gualteria, Lutz, Mosq. Brazil, p. 47 (1904).

? Danielsia, Theo., Entom. XXXVII, p. 78 (1904).

Pseudoculex, Dyar, Proc. Ent. Soc. Wash. VII, p. 47 (1905).

Chrysoconops, Ġoeldi, Os Mosq. no Pará, p. 114 (1905).

Reedomyia, Ludlow, Can. Ent. XXX VII, p. 94 (1905).

Pecomyia, Theo., J. Econ. Biol. I, p. 24 (1905).

Pseudograbhamia, Theo, J. Bomb. Nat. Hist. Soc., p. 244 (1905).

Phagomyia, Theo, Gen. Ins. Fam. Cul., p. 21 (1905).

Polyleptiomyia, Then., l.c.

Lepidotomyia, Theo., l.c., p. 22.

Lepidoplatys, Coq., Science, XXIII, p. 314 (1906).

? Cacomyia, Coquillet, U.S. Dept. Agric. Bull. II, p. 16 (1906).

? Stegoconops, Lutz, Imprensa Medica, (1906).

Pseudoskusea, Theo., Mon. Cul. IV, p. 192 (1907).

Pseudohowardina, Theo., Mon. Cul. IV, p. 223 (1907).

Protomacleaya, Theo., Mon. Cul. IV, p. 253 (1907).

Duttonia, Newst., Ann. Trop. Med. I, p. 17 (1907).

Mimeteculex, Theo., Third Rep. Wellc. Lab., p. 258 (1908).

Geitonomyia, Leic., Stud. Ins. Med. Res., Fed. Malay States, III, p. 134 (1908).

Myxosquamus, Theo., Mon. Cul. V, p. 225 (1910).

Neopecomyia, Theo., Mon. Cul. V, p. 261 (1910).

Stenoscutus, Theo., Mon. Cul. V, p. 263 (1910).

Bathosomyia, Theo., Mon. Cul. V, p. 267 (1910).

? Molpemyia, Theo., Mon. Cul. V, p. 479 (1910).

? Andersonia, Strickland, Entom., p. 250 (1911).

Leslieomyia, Christ., Paludism, No. 2, p. 68 (1911).

A query prefixed to a name in the above list of synonyms indicates that the genus was described from the female only, and consequently it may possibly 
belong to one of the other genera of the Aëdes group, though in each case the general appearance would seem to indicate an Ochlerotatus. Finlaya is perhaps the most distinct of the various groups which have received generic names, owing to the spotted wings and more or less tufted venter, but I have no hesitation in placing it as a synonym of Ochlerotatus. In the type species of Finlaya $(F$. poicilia, Theo.), the claws of the female were incorrectly described as simple; they are really toothed on the fore and mid legs.

Since writing in this periodical last October, I have seen specimens of what I take to be Ochlerotatus albifasciatus (Macq.) Arrib., from Mendoza, Argentina (G. Boag). This species is the type of the genus Ochlerotatus; the specimens referred to appeared to belong to the same group as the European O. aissalis.

Even in Ochlerotatus there is some variation in the form of the male palpi. The thickness of the two apical joints varies, and also their relative length as compared with the basal joint. In one species (O.irritans) the palpi are distinctly shorter than the proboscis, while in an Indian species they are only two-thirds as long. In $O$. simulans and $O$. apicoannulatus the last two joints are scarcely at all swollen, of about equal length and less hairy than usual. In spite of these differences, and the great variation in scale characters, it has not been found possible to split up the genus satisfactorily. In the majority of species the male palpi conform rather closely to the type found in O. hirsutus (Bull. Ent. Res. II, p. 249, fig. 1).

Ochlerotatus differs from Aëdes in having the male palpi elongate, about equal in length to the proboscis ; and from Stegomyia in having the last two joints of the of palpi more or less swollen, and with distinct hair tufts; the penultimate joint is a little longer and distinctly thicker than the terminal. There is apparently no structural character by which the females of Aëdes, Ochlerotatus, and Stegomyia can be distinguished, and this lends support to the view held by Dyar and Knab, that the three genera should all be merged into Aëdes. The difference in the males, however, is so striking, that it is difficult to see how they can all be regarded as belonging to one genus. The three genera are here treated as distinct, though it is recognised that they are much more closely related among themselves than any of them are to the Culex and Taeniorhynchus group.

A complete table of the African species is given. The arrangement of those species without flat scales on the scutellum has been altered, in order that they may be tabulated, so far as possible, by characters easily observable with a handlens. The structure of the hind claws is evidently of no great importance, and not even trustworthy for specific distinctions; Neveu-Lemaire in a large series of $S$. sugens found some specimens with both hind claws simple, some with both toothed, and some with one toothed and one simple.

The statement previously made that Ochlerotatus is mainly a Palaearctic genus is of course a complete error.

Table of African Ochlerotatus.

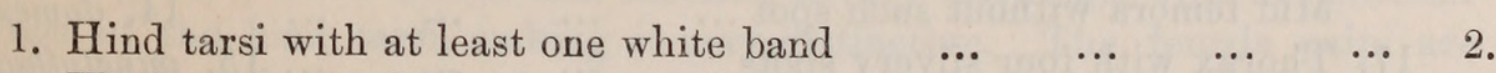
$\begin{array}{llllllll}\text { Hind tarsi entirely dark } & \ldots & \ldots & \ldots & \ldots & \ldots & \ldots & 13 .\end{array}$ 
2. First (i.e., metatarsus) and second tarsal joints only with white bands, that on the second joint much the broader

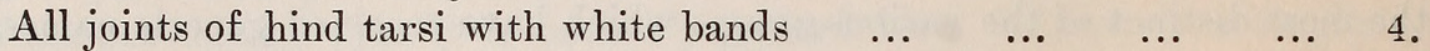

3. Thorax with a double median row and lateral patches of flat metallic

silvery scales; head silver-scaled ... $\quad \ldots \quad \ldots \quad$ 1. longipalpis.

Thorax laterally and head with whitish narrow-curved scales. 2. wellmani.

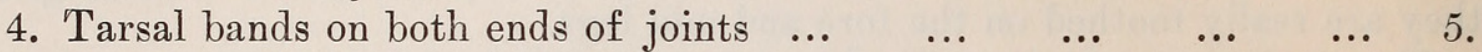

$\begin{array}{llllllll}\text { Tarsal bands on bases of joints only } & \ldots & \ldots & \ldots & \ldots & \ldots & 10 \text {. }\end{array}$

5. Small species (about $4 \mathrm{~mm}$.) ; tarsai bands clear white and almost

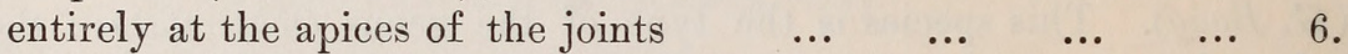

Larger species (about $6 \mathrm{~mm}$.) ; tarsal bands yellowish white and equally distributed on each side of the articulations $\quad \ldots \quad \ldots$

6. Thorax, and hind femora before the apex, with small silvery spots...

Thorax and hind femora without silvery spots, except at apex of the $\begin{array}{llllllll}\text { latter... } & \ldots & \ldots & \ldots & \ldots & \ldots & \ldots & 3 . \text { apicoannulatus. }\end{array}$

7. Spots of thorax composed of broad flat scales ; fore and mid femora with a silvery spot before apex $\quad \ldots \quad \ldots \quad \ldots \quad \ldots \quad$ 4. marshalli. Spots of thorax composed of narrow curved scales, wings with a silvery spot at base of costa; fore and mid femora unspotted.

5. simulans.

8. Thorax brown with two whitish longitudinal stripes... ... 6. dorsalis. Thorax almost uniformly brown or brassy brown ...

9. Abdomen almost all pale brown $\quad \ldots \quad \ldots \quad \ldots$ 7. longisquamosus. Abdomen dark brown banded with white $\quad \ldots \quad \ldots \quad$ 8. pulcritarsis.

10. Legs marbled, female palpi brownish, white-tipped $\ldots \quad \ldots \quad \ldots \quad \ldots \quad 11$. Legs not marbled, female palpi black, with a distinct white ring in middle

11. Wings mottled with black and white scales; dark species . Wings not mottled; more brownish species; costal fringe whitish beyond middle ...

10. hirsutus.

12. Abdominal segments with apical lateral yellowish spots. 11. durbanensis. Abdominal segments without such spots $\quad \ldots \quad \ldots\left\{\begin{array}{c}12 . \text { nigeriensis. } \\ \text { 12a. sudanensis. } \\ 12 \text { b. caballus. }\end{array}\right.$

13. Scutellum clothed with white or silvery scales, normally all flat, or head covered mostly with flat scales $\quad \begin{array}{llll}\ldots & \ldots & \ldots & \ldots\end{array}$ Scutellar scales neither flat nor white, head with only narrow scales $\begin{array}{llllllllll}\text { in middle } & \ldots & \ldots & \ldots & \ldots & \ldots & \ldots & \ldots & \ldots\end{array}$ utellar scales all white or silvery white and all flat (except in

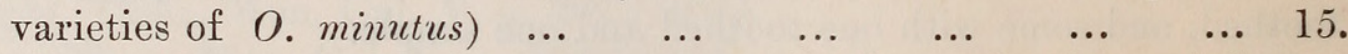
Scutellar scales partly black, some narrow; head mostly flat-scaled 23.

15. Hind femora with a round white spot before the apex $\quad \ldots \quad$.. 16 .

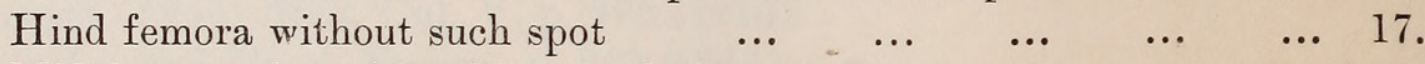

16. Mid femora also with white spot before apex... 13. argenteopunciatus. Mid femora without such spot ... $\quad \ldots \quad \ldots \quad \ldots \quad$... $\quad$ 14. domesticus.

17. Thorax with four silvery spots $\quad \ldots \quad \ldots \quad \ldots$ 15. punctothoracis.

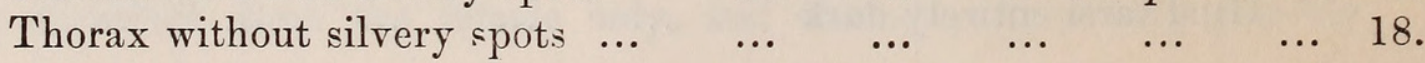


18. Thorax whitish at the sides, blackish in the middle; large species

16. ornatus.

Thorax not whitish at the sides ; smaller species

19.

19. Abdomen of female with distinct basal pale bands on all the segments; hind tibiæ not conspicuously white at apex. 17. alboventralis.

Abdomen of female all dark above (normally), though that of the male has distinct silvery basal bands on all the segments; hind tibiæ with a more or less conspicuous silvery white mark at the apex ...

20. Head-scales (in female) nearly all dark Head-scales largely pale

18. africanus.

1. Claspers of male genitalia formed like a two-pronged fork, head scales whitish ... $\quad$... 19. albocephalus. Claspers of male genitalia not fork-like, swollen at the tip ... $\quad \ldots \quad 22$.

22. Thoracic scales narrower, smaller, bronzy ochreous or yellowish more or less mixed with blackish brown ... ...

20. minutus. Thoracic scales broader, larger, dull ochreous $\quad \ldots \quad$ 21. abnormatis.

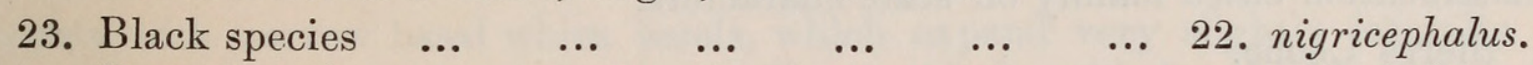

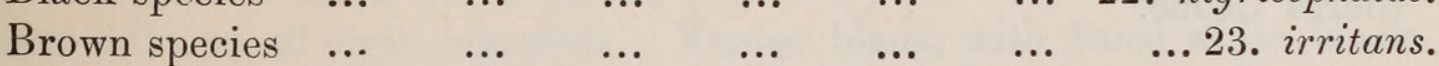

24. Very yellow species, recalling Taeniorhynchus aurites, etc. 24. ochraceus. Not yellow species (but a variety (?) of O. nemorosus is all ochreous) 25 .

25. Abdominal segments with complete basal pale bands $\quad \ldots \quad \ldots 26$. Abdominal segments without complete basal pale bands $\quad \ldots \quad$... 29 .

26. Wings, femora and tibiæ more or less marbled; Palaearctic species

25. nemorosus.

Wings, femora and tibiæ not at all marbled; Ethiopian species ... 27.

27. Hind claws of female simple ; thorax without distinct lines.

Hind claws of female toothed $\ldots \begin{array}{llllllll} & \ldots & \ldots & \ldots & \ldots & \ldots & \ldots & 28\end{array}$

28. Smaller species, very dark; thorax not lined $\quad \ldots \quad 27$. caliginosus. Larger, lighter-coloured species; thorax more or less ornamented $\begin{array}{llllll}\text { with yellowish lines } & \ldots & \ldots & \ldots & \ldots & 28 \text {. dentatus. }\end{array}$

29. Large species; thorax without distinct ornamentation; hind tibiæ with a small white spot at apex $\quad \ldots \quad \ldots \quad \ldots \quad$ 29. cumminsi.

Medium-sized species; thorax with distinct short golden lines in front of scutellum; hind tibiæ with a rather broad white band $\begin{array}{llllllll}\text { at } \operatorname{apex} & \ldots & \ldots & \ldots & \ldots & \ldots & \ldots & 30 \text {. leucarthrius }\end{array}$

1. O. longipalpis, Grünberg (Stegomyia), Zool. Anz. 1905, p. 383.

Stegomyia pollinctor, Graham, An. Mag. Nat. Hist. (8) V, p. 271 (1910).

Kingia pollinctor, Theo., Mon. Cul. V, p. 628 (1910).

This is a very distinct species which cannot possibly be confounded with any other, the general black colour and metallic silvery markings, with the peculiar markings of the hind tarsi, making it very distinctive. The female palpi are fully one-third as long as the proboscis, and somewhat swollen, and there are 
some other points of structure, noted elsewhere, in which this species diverges from typical Uchlerotatus.

S. Nigeria; Camerun; Togo.

2. O. wellmani, Theo. (Danielsia), Entomologist, XXXVIII, p. 103 (1905).

Angola; Sierra Leone (Daru, Ur. J. C. Murphy, I O taken June 1911); British East Africa (Mumias, T. J. Anderson, 1 q taken 29. iv. 1911).

3. 0. apicoannulatus, nom. n.

Aedimorphus alboannulatus, Theo., Entomologist, XXXVIII, p. 154 (1905), nec Cuiex (Ochlerotatus) alboannulatus, Macq., Dipt. Ex. Sup. IV, p. 10 (1850).

This forms, with the two following, a group of very closely allied species, distinguished collectively from all the rest of the genus, and in fact from all other Culicini, by the peculiar leg-markings (vide key). It is hardly worth while to point out that the fact that these three species have till now been placed in three different genera, affords one more proof of the absolute impracticability of a classification based mainly on scale characters.

Sierra Leone.

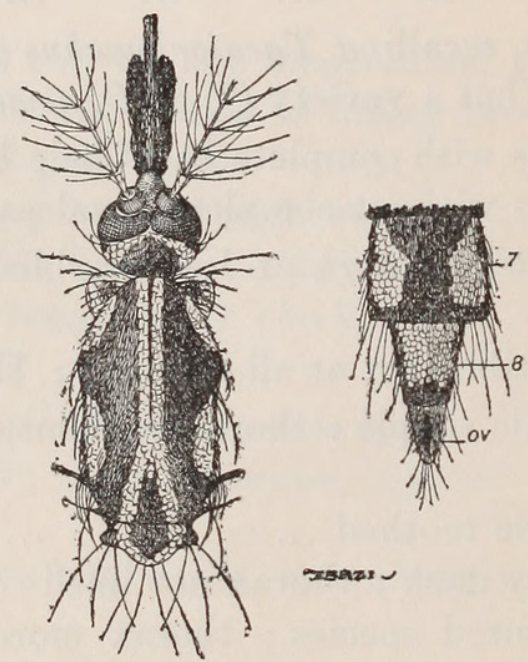

Fig. 3.-Ochlerotatus longipalpis, Grünb. Head and thorax, and apex of abdomen (우), ov. protruded ovipositor.

4. O. marshalli, Theo. (Stegomyia), Mon. Cul. I, p. 310 (1901).

Scutomyia marshalli, Theo., Gen. Ins. Culicidae, p. 19 (1905).

S. Rhodesia.

5. O. simulans, Newstead \& Carter (Reedomyia), Ann. Trop. Med. V, p. 240 (1911).

Seems only to differ from 0 . marshalli by the characters given in the key. One specimen (paratype) has the white spot on the hind femora only, not on the others, and Mr. Carter informs me that ${ }^{66}$ the spots on the fore and mid femora of the type are simply due to small patches of scales being rubbed off."

Ashanti. 


\section{O. fascipalpis, sp. n.}

ᄋ. Head clothed mainly with loosely applied flat scales, a few narrow curved and some upright forked on the nape, pale yellow; the flat scales are mostly pale yellow, but there are a few black ones in front, and a pair of sublateral triangular patches of the same colour. Antennae and clypeus black, first antennal joint with small whitish scales on the inside, clypeus bare. Palpi black-scaled, with a median white band; fully one-fourth as long as the proboscis, rather thin. Proboscis black-scaled, a few white scales in the middle of its upper surface. Thorax black, clothed above with black and pale yellow narrow curved scales; the distribution of colour will best be understood by a glance at the figure. Pleurae with patches of flat white scales. Scutellum with flat white scales on the median lobe. Wings with the veins clothed with black scales, a few white ones at the extreme base of the costa ; first fork-cell a little longer than second, its stem rather more than half its length. Auxiliary vein terminating at the costa just before base of first fork-cell. Legs black, femora whitish on the basal two-thirds, and at the extreme tip; all the tarsal joints with white basal bands, that on the metatarsus the narrowest. Claws of hind legs simple. Abdomen black-scaled, the segments with narrow basal white bands, which expand very slightly laterally and in the middle, on all eight segments. Venter black, with basal white bands on the first five segments. Ovipositor not visible. Length $4 \mathrm{~mm}$., without proboscis.

Type in the British Museum; presented by the Entomological Research Committee.

Described from a single female, in perfect condition, bearing the label "Little Ruaha River, South Usangu District, 3,500 ft., German E. Africa. 28. xi. 1910. S. A. Neave."

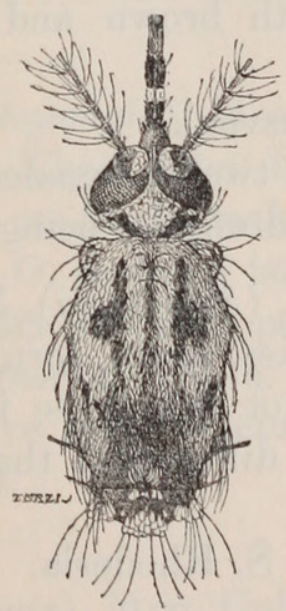

Fig. 4.-Ochlerotatus fascipalpis, sp. n.

This species most resembles $O$. hirsutus, but is much darker and has banded palpi and a flat-scaled scutellum. The thoracic adornment is very suggestive of $O$. wellmani, O. ornatus and $O$. lateralis, and perhaps the real relationships of the insect are with those species. The three last-mentioned, with $O$. longipalpis, form a distinct group, in which the eighth abdominal tergite in the female is larger and broader than usual, and the cerci are minute or absent; the male palpi of $O$. lateralis and $O$. longipalpis are scarcely swollen. This group, therefore. seems to connect Ochlerotatus with Stegomyia. 
10. O. hirsutus, Theo., Mon. Cul. I, p. 392 (1901).

Additional localities : British East Africa (Kitui, 7. vi. 1911, T.J. Anderson); Uganda (Busoga, Dr. Hoages); Gold Coast (one small female).

12. O. nigeriensis, Theo., Mon. Cul. V, p. 281 (1910).

Culicelsa fryeri, Theo., Trans. Linn. Soc. Lond., XV, 1, p. 84 (1912).

Additional locality : Bole, Gold Coast (Dr. A. Ingram); good series of both sexes bred from larvae.

12a. 0. sudanensis, Theo. (Culex), Fourth Rept. Wellc. Lab. Vol. B, p. 154 (1911).

This is evidently closely allied to $O$. nigeriensis, though the author does not compare it with that species, since he places it in Culex. He does not say whether there are any white scales on the wings, and so it may not be correctly placed in the table. Apparently it is distinct from O. nigeriensis, since the thorax is described as " tesellated with golden brown and deep brown, showing traces of linear arrangement." In $O$. sudanensis the proboscis is said to be unbanded, in $O$. nigeriensis it is pale in the middle beneath and at the sides.

Sudan.

12b. 0. caballus, Theo., Entomologist, XLV, p. 93 (1912).

Grabhamia caballa, Theo., l.c.

" $\mathrm{O}$. Head and thorax with rich deep golden scales, a dark patch on each side of the head. Thorax showing traces of linear markings, and with golden chaetae. Palpi and proboscis deep brown : antennae brown. Abdomen deep brown, with basal creamy bands which spread out to form large lateral spots, and also send out median processes which in some specimens form a dorsal line. Legs brown, mottled with creamy scales, and with prominent basal pale bands; ungues all equal and uniserrate. Wings with brown and creamy scales. Length 4 to $5 \mathrm{~mm}$.

" Habitat.-Onderstepoort, Transvaal.

"Observations.-Described from twelve females. It comes near G.durbanensis, Theob., but can be told by the hind ungues being uniserrate."

13. O. argenteopunctatus, Theo. (Stegomyia), Mon. Cul. I, 316 (1901).

This and the two following species, again, form a very closely allied group, and it may be doubted whether or not the three forms are really distinct: there appear to be no other constant differences than those given, though there is considerable variability.

Sudan; N. Nigeria; Uganda; S. Rhodesia.

14. O. domesticus, Theo. (Uranotaenia), Mon. Cul. II, p. 253 (1901). Aedimorphus domesticus, Theo., Mon. Cul. III, p. 291 (1903).

S. Nigeria ; Ashanti; Uganda.

1\%̃. 0. punctothoracis, Theo. (Aedimorphus), Ann. Mag. Nat. Hist. (8) V, p. 374 (1910).

Aedimorphus punctithorax, Theo., Mon. Cul. V, p. 205 (1910).

It should be mentioned here that the figure given by Theobald (Mon. V, p. 206) to represent the male genitalia of this species, in reality refers to 0 . albocephalus. 
The slide no doubt was wrongly labelled. Very abundant at Accra. One of the two females labelled "Stegomyia argenteopunctata, type" by Theobald is this species.

Gold Coast ; Angola; S. Rhodesia.

16. O. ornatus, Mg., Syst. Bes. I, p. 5 (1818).

The specimen recorded by Theobald (Mon. Cul. III, p. 191) as Culex lateralis, Mg., is, I find, not that species, but closely related to it and probably referable to O. ornatus. When I included O. lateralis as African in my table (Bull. Ent. Res. Oct. 1911, pp. 248, 250), I had not examined the specimen. O. ornatus has complete pale bands on the abdomen, whereas $O$. lateralis has only lateral pale spots at the base of each segment. In the Algerian specimen referred to and in another from Fez, Morocco (May 1909, Major C. E. P. Fowler), the scutellum bears mostly flat white scales (the Algerian specimen is considerably denuded). As these are the only two specimens of $O$. ornatus which I have seen, I cannot say whether the flat-scaled scutellum is normal or not. Ficalbi attributes the name $C$. ornatus, $\mathrm{Mg}$. to another species.

17. O. alboventralis, Theo. (Protomacleaya), Mon. Cul. V, p. 251. Angola.

18. 0. africanus, Newstead (Duttonia), Ann. Trop. Med. 1, p. 20 (1907).

The name africanus is retained for the present, but if Ochlerotatus and Stegomyia be merged, it will be preoccupied by S. africana, Theo., similarly if Taeniorhynchus africanus, Neveu-Lemaire be shown to be an Ochlerotatus, a new name will have to be proposed for Newstead's species.

0 . africanus was described from a single female, and its validity as a species is somewhat doubtful. It seems, however, to be distinct by the character given in the key. The thorax is rubbed, but the scales appear to be all dark.

Congo.

19. O. albocephalus, Theo. (Stegomyia), Mon. Cul. III, p. 140 (1903).

Polyleptiomyia albocephala, Theo., Gen. Ins. Culicidae, p. 21 (1905).

This species is only known to me in the male sex. It is possible that its female may have been included under $O$. minutus, but if so I do not see how to distinguish them. The male genitalia are very peculiar and have been figured by Theobald as those of $O$. punctothoracis (Mon. Cul. V, p. 206, fig. 79). Of the mosquitos whose genitalia I have seen, O.cumminsi alone exhibits a somewhat similar structure in these organs.

Gambia ; Gold Coast.

20. 0. minutus, Theo. (Stegomyia), Mon. Cul. I, p. 319 (1901).

Duttonia tarsalis, Newstead, Ann. Trop. Med. I, p. 18 (1907).

Reedomyia biannulata, Theo., Mon. Cul. IV, p. 263 (1907).

Reedomyia neobiannulata, Theo., Mon. Cul. V, p. 255 (191(').

Reedomyia bipunctata, Theo., Mon. Cul. V, p. 256 (1910).

Neopecomyia uniannulata, Theo., Mon. Cul. V, p. 261 (1910).

Stenoscutus africanus, Theo., Mon. Cul. V, p. 263 (1910).

Reedomyia seychellensis, Theo., Trans. Linn. Soc. Lond. XV, 1, p. 83 (1912). 
This is a variable species, and not very easy to recognise. Between extreme forms there is considerable difference in the colour and form of the scales, but I can find no constant differences between the forms enumerated above, and so have included them all as one species under the oldest name. I may be wrong in this, but if there is more than one species more material and more minute study will be required before they can be properly separated. It is with some reluctance that I accord specific rank to $O$. africanus, Newstead (described from one female) and $O$. alnormalis, Theo. (described from two males, one dissected). The most characteristic features of the different forms may be briefly pointed out.

i. Typical form (minutus). Head bearing flat scales over the occiput; scales dark in the middle and at the sides, leaving a V-shaped pale area. Pale scales of thorax forming a pair of distinct spots about the middle of the mesonotum.

ii. var. tarsalis (= bipunctatus). Like the type form, but without flat scales over the top of the head, the scales in this position being narrow and curved. This difference, which is regarded as of generic value by Theobald, is not constant, and intermediates occur between these two varieties. Some specimens from Uganda are larger than those from Ashanti and have the pale spots on the thorax less marked; the integument is dark brown instead of red-brown.

iii. var. biannulatus (= neobiannulatus). Head scales all pale in the middle ; thorax without distinct pale spots, though the light and dark scales are not evenly mixed; abdomen of female sometimes with traces of pale bands at the bases of segments (lateral white spots are always present). $R$. neobiannulata was proposed by Theobald, without any apparent reason, as a substitute for $R$. biannulata, which was founded on some males from Sierra Leone. Although the female of $R$. biannulata was undescribed, we were given characters by which it might be distinguished from $R$. neobiannulata, and also the male genitalia of the two were said to differ, even though both names were given to the same specimens.

iv. var. uniannulatus. Like the preceding, but there are some narrow scales on the apical portion of the middle lobe of the scutellum.

v. var. stenoscutus, nom. nov. (= africanus, Theo., nec O. africanus, Newst.). This is the most distinct of the varieties of this species. The abdominal segments of the female have distinct pale basal bands; the scutellum bears a considerable number of narrow scales, mostly on the middle lobe (but this character is variable); the hind femora are whitish beneath on the whole of their length (in the other varieties they are usually darkened towards the apex on the under side); in some specimens the white spot at the apex of the hind tibiae is rather indistinct.

Sierra Leone; Ashanti; Gold Coast; Uganda; Congo; Angola ; Seychelles Is.

\section{O. abnormalis, Theo. (Bathosomyia), Mon. Cul. V, p. 258 (1910).}

The hind claws $\left(0^{*}\right)$ are unequal and simple. The genus Bathosomyia seems to have been founded principally on the characters of the male genitalia; but in the single mounted specimen these organs cannot be properly made out. They seem to be similar to those of the preceding species.

Ashanti. 
22. O. nigricephalus, Theo. (Stegomyia), Rept. Liverp. S. Trop. Med. Mem. IV, app. (1901).

Phagomyia nigricephala, Theo., Gen. Ins. Culicidae, p. 21 (1905).

Myxosquamus paludosus, Graham, Ann. Mag. Nat. Hist. (8) V, p. 270 (1910).

This species should be easily recognised by its almost uniform black colour, the only other black species being O.caliginosus, which has basal white bands on the abdominal segments, while in this species there are only white lateral spots. $O$. nigricephalus has a similar scutellar scaling to that of the following species, but the scales are all black. The type of $O$. nigricephalus appears to have been lost (it is missing from the British Museum Collection), but from the description, and from a damaged specimen so named by 'I'heobald, there seems little doubt that it is the same as Graham's species.

S. Nigeria.

23. 0. irritans, Theo. (Stegomyia), Rept. Liverp. S. Trop. Med., Mem. IV, app. p. iii. (1901).

Catageiomyia senegalensis, Theo., Rept. Liverp. S. Trop. Med., Mem. XI, app. p. 1 (1903).

Aedimorphus albotacniatus, Theo., Mon. Cul. V, p. 204 (1910).

Myxosquamus confusus, Theo., Mon. Cul. V, p. 225 (1910).

Phagonyia irritans, Theo., Gen. Ins. Culicidae, p. 21 (1905).

The members of the group to which $O$. irritans belongs are not very easily separated. Perhaps the best character for this species is the scaling of the scutellum. The middle lobe bears a variable number of cream-coloured narrow curved scales, mixed with flat black ones, some or all of the flat ones being occasionally also cream-coloured; the lateral lobes bear only creamy narrow curved scales. The abdominal segments have narrow basal pale bands; the tip of the hind tibiae is white, but not conspicuously so. It thus approaches rather closely to O. minutus var. stenoscutus. The species seems to be very abundant at Accra.

There is no doubt about the synonymy given above. The remarks made concerning $O$. apicoannulatus (p. ) might be applied with added force here.

Senegal; Gold Coast; S. Nigeria.

24. O. ochraceus, Theo., Mon. Cul. II, p. 103 (1901).

Additional locality : British East Africa (C.W.Woodhouse and W. Kennedy).

26. 0. quasiunivittatus, Theo., Mon. Cul. II, p. 32 (1901).

Additional localities: British East Africa; Uganda.

28. 0. dentatus, Theo. (Culex), First Rept. Wellc. Lab., p. 75 (1905).

Culex pallidopunctata, Theo., U. South Afr. Dept. Agric., First Rept. Vet. Res., p. 267 (1911).

Theobald does not compare $C$. pallidopunctata with $O$. dentatus, but describes the hind claws of the female as being simple; he states that $C$. pallidopunctata was described from a series of 58 females. Evidently this series was really a mixed one, for out of four females presented by him to the British Museum, two (including the holotype) are typical $O$. dentatus with toothed hind claws; one appears to be $O$. quasiunivittatus from the thoracic scaling, but the hind tarsi are missing; the fourth is a Culex pipiens var. pallidocephalus ! 
29. 0. cumminsi, Theo., Mon. Cul. III, p. 214 (1903).

Additional locality : British East Africa (S. slopes of Mt. Elgon, 5100$5800 \mathrm{ft} ., 8-13 . v i .11 .$, S. A. Neave); three small females, typical in other respects.

It is highly improbable that the egg-raft figured by Theobald (Mon. Cul. V, p. 395) has anything to do with this species.

Genus Mansonioides, Theo.

Mon. Cul. IV, p. 498 (1907).

? Etorleptiomyia, Theo., First Rept. Wellc. Lab., p. 71 (1904).

?Etiorleptiomyia, Theo., Mon. Cul. V, p. 454 (1910).

? Etorilepidomyia, Alcock (emend.), Ann. Mag. Nat. Hist. (8) VIII, p. 249 (1911).

Diceromyia, Theo., Fourth Rept. Wellc. Lab., Vol. B, p. 151 (1911).

The genus Diceromyia was founded on characters of the male genitalia of a species (from the Sudan) which must be very close indeed to Mansonioides nigra, Theo. Apart from the forked claspers, however, there does not seem to be any great peculiarity in this insect, which I have not seen. The description of the male palpi is quite sufficient to show that Diceromyia is synonymous with Mansonioides, and the close resemblance of the female to $M$. nigra removes any doubt that that species is correctly placed here. $D$. africana $Q$ is said to differ from $M$. nigra in the absence of the white bands of the palpi and of the irregular white apical bands to the abdominal segments, and also in the fore and mid claws being toothed. This last statement is in all probability an error, as no member of the Culex-Taeniorhynchus group has toothed claws in the female. The name africana is preoccupied in this genus.

M. (?) mediolineata, Theo. (Etorleptiomyia), FirstRept. Wellc. Lab., p. 71 (1904).

Etorleptiomyia mediopunctata, Theo., Gen. Ins. Culicidae, p. 44 (1905).

Anisocheleomyia quadrimaculata, Newstead, Ann. Trop. Med. 1, p. 32 (1907).

In comparing the types of $E$. mediolineata and $A$. quadrimaculata the only differences I could detect were slight ones in the wing-markings, and it seems best to regard these as within the range of individual variation, especially as the two previously recorded specimens differ in this respect. The markings of the wings recall those so often found in Anopheles, e.g. A. costalis. So far as I can see there is no difference in breadth between the two claws on any of the legs of the type of A. quadrimaculata.

Additional locality: Upper Shire River, Nyasaland, 3. viii. 11 (Dr. J. B. Davey).

Leicester describes as Etorleptiomyia completiva a very distinct species (from one male), which from the structure of the proboscis and palpi is evidently an Ingramia (see p. 43). He says the wing-scales are exactly as in E. mediolineata.

Genus Ä̈рomyia, 'Theo. (emend.)

Aedeomyia, Theo., Mon. Cul. II, p. 218 (1901).

The relationships of this genus seem to be with Taeniorhynchus, as is indicated (1) by the structure of the male claws; (2) by the broad dense wing-scales. 
1. A. catasticta, Knab, Ent. News, XX, p. 387 (1909).

A. squammipenna, Theo., Mon. Cul. II, p. 219 (1901), part (nec Aëdes squamipennis, Arrib.).

Knab described $A$. catasticta from the Philippine Islands, and says of it, "This species much resembles Aedeomyia squamipennis Arrib., but differs in many details, and these differences appear to be constant. In A. squamipennis the proboscis has a broader white ring and the spot behind it is larger and yellow while the apical white ring is very narrow. In A. squamipennis the palpi, besides the white apex, have a large yellow patch in the middle. On the mesonotum the ocher-yellow scales are distributed nearly over the entire surface and the white spots on the wings are much smaller than in the Philippine specimens. The male genitalia of the two species show specific differences." Before reading Knab's description I had separated the British Museum series of Aëdomyia squamipennis into two species, one occurring in S. America only and the other from the Ethiopian and Oriental regions; on comparing the latter with the description of $A$. catasticta, it was found to apply in almost every detail both to the African specimens and those from the Oriental region. To the distinctions given by Knab between $A$. catasticta and $A$. squamipennis I can add another which seems to be constant and is easily seen ; the white ring embracing the tip of the metatarsus and the base of the second tarsal joint of the hind legs is narrow in A. squamipennis, but broad and rather conspicuous in A. catasticta.

Sudan; S. Nigeria; N. Nigeria; Gold Coast.

2. A. africana, Neveu-Lemaire, Arch. Parasit. X, p. 273 (1906).

Differs from $A$. catasticta in having the palpi entirely dark brown, the proboscis has only a median pale ring.

Dufile.

Genus Taeniorhynchus, Arrib.

Rev. Mus. La Plata, II, p. 147 (1891).

Panoplites, Theo., Mon. Cul. II, p. 173 (1901).

Mansonia, Blanch., C.-R. Soc. Biol. LIII, p. 1046 (1901).

Coquillettidia, Dyar, Proc. Ent. Soc. Wash. VII, p. 47 (1905).

Rhynchotaenia, Brèthes, An. Mus. Buenos Ayres, XX, p. 470 (1910).

Pseudotaeniorhynchus, Theo., Novae Culicidae, I, p. 19 (1911).

Theobald substitutes the name Pseudotaeniorhynchus for those species which he formerly included in Taeniorlynnchus, his Panoplites (= Mansonia) sinking under Taeniorhynchus, Arrib. But T. fasciolatus, Arrib., which Theobald specified as the type of his modification of Arribalzaga's genus, is quite a typical Taeniorhynchus, and hence Pseudotaeniorhynchus, Theo., is synonymous with Taeniorhynchus, Arrib. According to the Zoological Record for 1910, Brèthes had previously substituted Rhynchotaenia for Taeniorhynchus, Theo.; I have been unable to consult this paper.

3. T. aurites, Theo., Mon. Cul. II, p. 209 (1901).

Chrysoconops fraseri, Theo. (Novae Culicidae, I, p. 22, 1911), is a synonym. 
3a. T. microannulatus, Theo. (Chrysoconops), Novae Culicidae, I, p. 26 (1911).

This is a distinct species, but closely allied to $T$. aurites from which it differs principally in the colour of the hind legs : in $T$. aurites the tibia has a median dark ring and a dark tip, the first three tarsal joints have rather broad apical dark bands, and the last two are entirely dark; in $T$. microannulatus, on the contrary, the hind tibia is entirely yellow, and the tarsal joints are only very narrowly black at the apex. In the male the palpi are entirely yellow, not spotted with black as in $T$. aurites. The oriental $T$. ochraceus, Theo., differs in having a small black ring near the tip of the hind femora, and blackish marks at the base and apex of the hind tibiae. T. ochraceus has been redescribed by Knab (Ent. News, 1909, p. 386) as Mansonia chrysogona, owing to an error in the original description, Theobald stating that the upright scales of the head are black, when actually they are yellow. The specimens recorded from Bahr-elJabel, Anglo-Egyptian Sudan, by Theobald, as T. aurites (First Rept. Wellc. Lab., p. 77) are not that species, but T. microannulatus.

Sudan; Uganda.

4. T. annettii, Theo., Mon. Cul. II, p. 205 (1901).

Add to synonymy: Chrysoconops maculipennis, Theo., Novae Culicidae, I, p. 27 (1911).

5. T. cristatus, Theo., First Rep. Wellc. Lab., p. 78 (1904).

Additional localities: Portuguese Congo (San Salvador, Dr. M. Gamble); Sierra Leone (Dr. J. C. Murphy).

6. T. fuscopennatus, Theo., Mon. Cul. III, p. 265 (1903).

Add to synonymy: Chrysoconops bakeri, Theo., Novae Culicidae, I, p. 19 (1911); Culex grandidieri, Blanchard, Les Moust., p. 627 (1905); and Culex flavus, Ventrillon, Bull. Mus. Paris, X, p. 550 (1904), (nec C. favus, Motschulsky, 1859).

Ventrillon describes the dorsal surface of the abdomen as entirely yellow, but the mesonotum as brown and not black. Specimens (four $Q$ ) answering to this description have been received from Zanzibar (Dr. W. M. Aders), but I do not think they are specifically distinct from $T$. fuscopennatus, in which the abdomen is banded. T. cristatus is distinguished from these Zanzibar examples only by its black mesonotum, and may therefore prove to be merely a variety of this species.

Taeniorhynchus perturbans, Walk., has been recorded as African by Laveran and Blanchard, and their records have been copied by Bezzi and Neveu-Lemaire. Reference to this species was inadvertently omitted in my previous paper, but it is very unlikely that $T$. perturbans is really an African species, since it was first described from the United States, and is now quite well known there. Prof. Blanchard and Dr. Laveran both inform me that the specimens on which the records were founded have been lost, so that there is no possibility of verifying them, but it seems quite possible that the species in question was really Mansonioides uniformis, especially since Dr. Laveran says it was very abundant 
at. Djibuti. He said it agreed with $T$. perturbans in having simple claws in the female, and basal white bands on the tarsal joints; only two African species known to me have these characters-Howardina gebeleinensis and $M$. uniformis, and the former is ruled out on account of its rarity.

\section{Genus Theobaldia, N.-L。}

C. R. Soc, Biol., 1902, p. 1331.

Culiseta, Felt, New York State Mus. Bull. 79, p. 391c (1904).

? Culicella, Felt, l.c.

Pseudotheobaldia, Theo., Mon. Cul. IV, p. 271 (1907).

Theobaldinella, Blanch., Les Moustiques, p. 390 (1905).

The last two joints of the male palpi are about equal in length (in my previous paper it was erroneously stated that the terminal joint is "longer than the penultimate"). The third (last) joint is distinctly thicker than the second.

\section{Genus Culex, L.}

\section{Syst. Nat. Ed. X (1758).}

Heteronycha, Arrib., Rev. Mus. La Plata, II, p. 56 (1891).

Lutzia, Theo., Mon. Cul. III, p. 155 (1903).

Lasioconops, Theo., Mon. Cul. III, p. 235 (1903).

Melanoconion, Theo., Mon. Cul. III, p. 238 (1903).

Heptaphlebomyia, Theo., Mon. Cul. III, p. 336 (1903).

Trichopronomyia, Theo., Ann. Mus. Nat. Hung., p. 98 (1905).

Neoculex, Dyar, Proc. Ent. Soc. Wash. VII, p. 47 (1905).

Pseudoheptaphlebomyia, Ventr., Bull. Mus. Paris XI, p. 427 (1905).

Mochlostyrax, D. \& K., Journ. N. Y. Ent. Soc. XIV, p. 223 (1906).

Jamesia, Christophers, Sci. Mem. Med. Ind., N. S. XXV, p. 12 (1906).

Maillotia, Theo., Mon. Cul. IV, p. 274 (1907).

Aporoculex, Theo., Mon. Cul. IV, p. 316 (1907).

Leucomyia, Theo., Mon. Cul. IV, p. 372 (1907).

? Microculex, Theo., Mon. Cul. IV, p. 461 (1907).

Oculeomyia, Theo., Mon. Cul. IV, p. 515 (1907).

Grabhamia is not, as stated in my previous paper, a synonym of Culex; the type species, though possessing simple claws in the female and male palpi similar to those of Culex, has the female abdomen of the Aëdes type, and so Grabhamia must be placed near Howardina. Messrs. Dyar and Knab include it in Janthinosoma, which it closely resembies in the structure of the male palpi.

As several new species have been described or are recorded as new to the African fauna, a fresh table of species has been given, and the opportunity has been taken of including Dr. Neveu-Lemaire's species in it; although I am still unable to recognise these, they seem to be distinct, so far as can be made out from the descriptions.

1. Proboscis and tarsi with pale bands, those on tarsi including both ends of joints

Tarsi unbanded ... 
2. Thorax with pale scales on the anterior two-thirds, or at least with a transverse pale band behind the middle... $\quad \ldots \quad \ldots \quad \ldots$

Thorax almost uniformly coloured, at most with a pair of pale spots ; abdominal segments with complete basal white bands ...

3. Wing-scales all, or nearly all, dark; abdomen usually almost

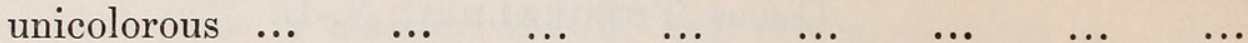

Wings with numerous light scales; abdomen with conspicuous $\begin{array}{lllllllllll}\text { markings } & \ldots & \ldots & \ldots & \ldots & \ldots & \ldots & \ldots & \ldots & 5 \text {. }\end{array}$

4. Femora and tibiae with rows of sharply defined white spots 1. quasigelidus. Femora and tibiae marbled but not spotted

2. consimilis.

5. Abdominal segments with complete apical yellowish bands; wing-

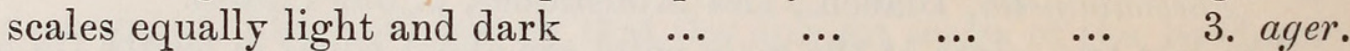

Abdominal segments with both median basal and lateral apical triangular pale spots; on the wings the dark scales preponderate $\quad \ldots \quad \ldots \quad \ldots \quad \ldots$

4. annulioris.

6. Lateral dark lines on thoracic integument outwardly concave 5. zeltneri.

7. Middle tibiae with a whitish lateral stripe ; abdominal bands broadest in middle; band of proboscis broad and ill-defined $\ldots 6$. duttoni. Middle tibiae unstriped; abdominal bands of equal breadth throughout ; band of proboscis narrower and more clearly defined

8.

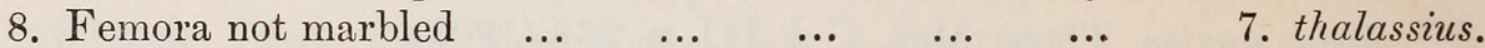
$\begin{array}{lllllll}\text { Femora marbled } \ldots & \ldots & \ldots & \ldots & \ldots & \ldots & \text { 8. somaliensis. }\end{array}$

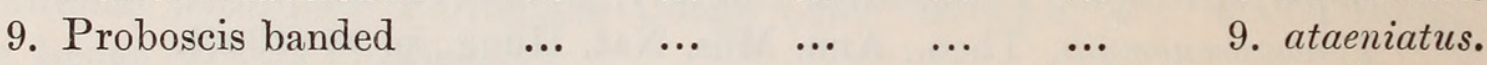
Proboscis unbanded (but compare $C$. tigripes and $C$. univittatus, both of which sometimes show traces of a median pale band on the $\begin{array}{lllllllllll}\text { proboscis) } & \ldots & \ldots & \ldots & \ldots & \ldots & \ldots & \ldots & \ldots & 10 .\end{array}$

10. Thorax with four well-defined silvery spots ... 10. argenteopunctatus. $\begin{array}{lllllllll}\text { Thorax without silvery } \operatorname{spots} & \ldots & \ldots & \ldots & \ldots & \ldots & \ldots & 11 .\end{array}$

11. Large species; femora and tibiae spotted $\quad \ldots \quad \ldots \quad \ldots 11$. tigripes. Medium-sized species; legs not spotted (except sometimes in $\begin{array}{lllllllll}\text { tipuliformis }) . . . & \ldots & \ldots & \ldots & \ldots & \ldots & \ldots & \ldots & 12 .\end{array}$

12. Legs somewhat striped as in Ochlerotatus ochraceus (on the fore leg the pale stripe is more or less broken up into spots, recalling $\begin{array}{llllllll}\text { C. } \text { tigripes }) & \ldots & \ldots & \ldots & \ldots & \ldots & \ldots & 12 \text {. tipuliformis. }\end{array}$

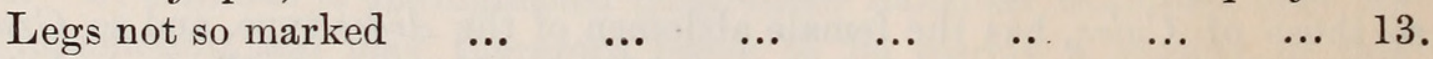

13. Tibiae striped with whitish, much as in C. duttoni; "seventh vein" more distinct than usual, and generally bearing a few scales

13. univittatus. Legs uniformly brownish or yellowish (except for pale knee-spots)... 14.

14. General coloration tawny; proboscis clear yellow; legs tawny

Proboscis and legs dark brown or blackish

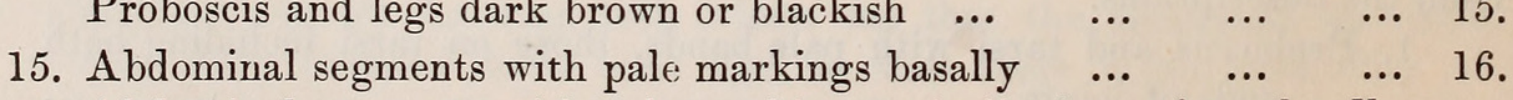
Abdominal segments with pale markings apically (sometimes hardly perceptible) ... 
16. Abdominal segments with basal banding in both sexes (in $C$. decens $\subsetneq$ the pale bands are often very narrow) $\quad \ldots \quad \ldots \quad \ldots \quad \ldots$ Abdominal segments with basal lateral pale spots, in the $\delta$ often united in the middle forming an irregular shaped band ... ...

17. Larger species; abdominal bands yellowish; a line of white scales on the under side of the last two joints of the male palpi

15. pipiens group.

Smaller species ; abdominal bands white ... $\quad \ldots \quad 18$.

18. Thoracic scaling uniformly reddish brown, ô palpi all dark 16 decens. Thoracic scaling partly bronzy-brown and partly brassy, the latter often predominating; male palpi as in $C$. pipiens

17. simpsoni.

19. Thorax all pale-scaled, integument with lateral pale areas in front; abdominal spots large in both sexes $\quad \ldots \quad \quad \ldots \quad \quad \ldots$ 18. pruina. 'Thorax not all pale-scaled, integument uniformly dark $\quad \ldots \quad \ldots 20$.

20. Thorax with two distinct pale areas near the middle...19. ornatothoracis. $\begin{array}{lllllll}\text { Thorax with uniform scaling or nearly so } & \ldots & \ldots & \ldots & \ldots & 21 .\end{array}$

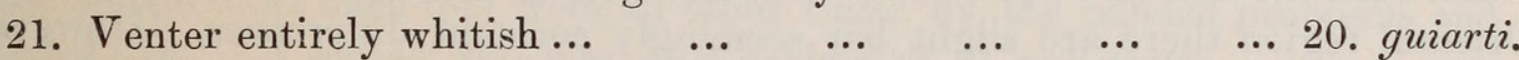
Venter with dark bands on the apices of the segments $\quad \ldots \quad \ldots 22$.

22. Bases of fork-cells in $\bigcirc$ equidistant from wing base ... 21. grahami. Base of first fork-cell nearer wing-base than that of second... $\quad \ldots \quad 23$.

23. Larger species (usual 5-6 mm.); thorax with reddish brown scales (intermediates seem to occur between this and some of the

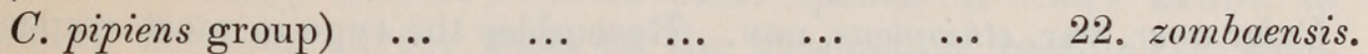
Smaller species (usually 3-4 mm.) ; thorax with dark brown scales (compare with $C$. guiarti; both often have a green thorax)

23. invidiosus.

24. Abdomen with complete apical bands on at least some of the segments 25 .

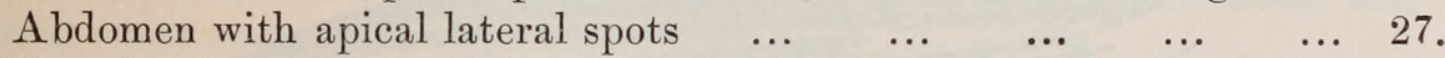

25. Terminal joint of $Q$ palpi short and thick $\quad \ldots \quad \ldots \quad$ 24. salisburiensis.

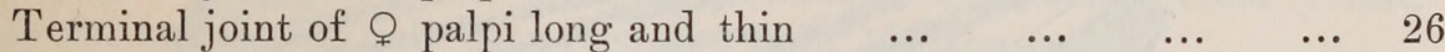

26. Abdominal segments 2-7 with apical pale bands $\quad \ldots \quad \quad \ldots 25$. piliferus. Abdominal segments 2-5 $\quad, \quad, \quad \ldots 26$. insignis.

27. Thoracic integument black, scales black or blackish... $\quad \ldots \quad 27$. rima. $\begin{array}{llllllll}\text { Thoracic integument reddish } & \ldots & \ldots & \ldots & \ldots & \ldots & \ldots & 28 \text {. }\end{array}$

28. Scales and bristles of thorax reddish brown $\ldots \quad \ldots \quad \ldots 28$. sergenti. Scales and bristles of thorax black $\quad \ldots \quad \ldots \quad \ldots \quad \ldots \quad$ 29. rubinotus.

1. C. quasigelidus, Theo., Mon. Cul. III, p. 181 (1903).

Add to synonymy: Culex par, Newst., Ann. Trop. Med. I, p. 25 (1907).

The leg-spots are quite distinct. The front of the mesonotum is whiter than usual.

Additional locality : Gold Coast.

2. C. consimilis, Newst., Ann. Trop. Med. I, p. 23 (1907).

Additional localities: Brit. E. Africa (T. D. Nair); Gold Coast (Dr. A. Ingram). 
This species seems to be variable; or there may be more than one here. Some specimens show narrow basal bands, others distinct apical lateral spots, on the abdominal segments; but the wing-scales are never mottled, and the ornamentation of the abdomen, when present, never has any resemblance to that found in the next two species.

\section{C. ager, Giles, Entomologist, XXXIV, p. 196 (July, 1901).}

My statement that this is not an African species proves to be incorrect. A single male specimen from Maiduguri, N. Nigeria, June, 1911 (Dr. W. D. Inness) is C. ager ; and a series has been bred from larvæ from Bole, Gold Coast (Dr. A. Ingram). It differs from $C$. consimilis (1) in having broad distinct apical pale bands on the abdominal segments, as well as a pale basal band on segment 8 ; (2) in the strongly marbled wings.

To the synonymy previously given for this species may be added: Culex infula, Theo., Mon. Cul, I, p. 370 (1901).

Between the African specimens and those in the British Museum from the Oriental region there are slight but seemingly constant differences. However, the description of $C$. ager given by Dr. Leicester applies quite well to the African form, and as the resemblances are so great, and the species in the Oriental region is undoubtedly variable, it is considered unwise to regard these specimens as representing a distinct species. They may, however, be given a varietal name, the variety being characterised as follows:-

Culex ager, var. ethiopicus, nov. Resembles the type in most respects, but (1) there is no pale spot at the apex of the proboscis above, as nearly always is the case in Oriental specimens; (2) the wing scales are larger, broader and

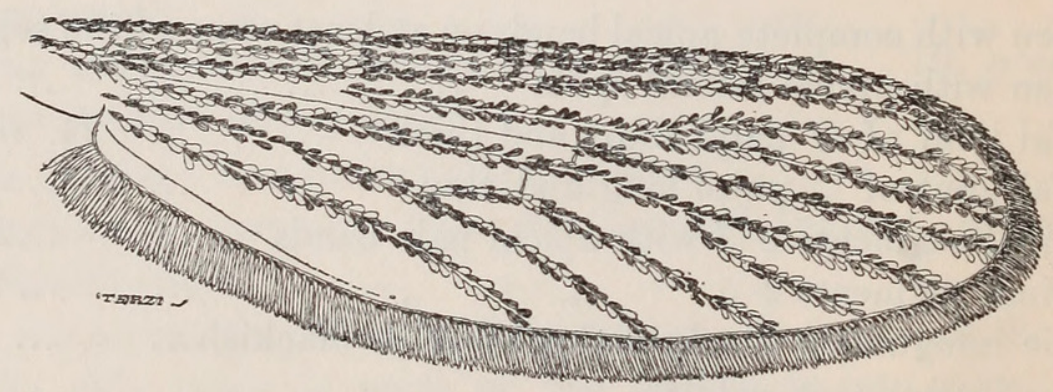

Fig. 5.-Culex ager, Giles, var. n. ethiopicus. In some specimens many of the scales on the forked veins are rather narrower than those shown in the figure.

denser, the light ones being quite as numerous as the dark (in the type form they are usually less numerous); (3) the bands on the abdomen are a lighter yellow. In some specimens the thorax shows a distinct green colour, as is so often the case in freshly hatched specimens. The lateral vein-scales vary somewhat in breadth.

4. C. annulioris, Theo., Liverp. S. Trop. Med., Mem. IV, App. p. v (1901). Culex neireti, Ventrillon, Bull. Mus. Paris, XII, p. 103 (1906).

Additional locality: Gold Coast (Bole, Dr. Ingram); Madagascar (Dr. Ventrillon). 
5. C. zeltneri, N.-L., Arch. Parasit. X, p. 251 (1906).

This species seems to differ from $C$. thalassius in the ornamentation of the mesothoracic integument. Judging from M. Neveu-Lemaire's figure, the median pair of dark lines are less distinct and closer together, while the broader lateral dark lines are concave outwardly, instead of convex as in most other species of Culex.

Abyssinia.

6. C. duttoni, Theo., Rept. Liverp. S. Trop. Med., Mem. V, App. p. v (1901). Additional locality : Uganda.

9. C. ataeniatus, Theo., U. South Afr. Dept. Agric., First Rept. Vet. Res., p. 261 (1911).

Described as "Proboscis dark at base and apex, dull ochraceous in the middle, forming a broad pale band . . . abdomen brown with narrow basal pale bands . . . legs brown, unbanded . . . Length $3 \mathrm{~mm}$. . . A single perfect female. At once told from all other Culex by the banded proboscis and unbanded legs." I suspect this may be a variety of C. univittatus.

Transvaal.

10. C. argenteopunctatus, Ventr. (Heptaphlebomyia), Arch. Parasit. IX, p. 446 (1905).

This species is remarkably distinct from all other species of Culex known to me on account of the four silvery spots on the mesonotum, recalling to some extent Ochlerotatus punctothoracis. In the present species, however, these spots, and a broad silvery margin to the eyes, are composed of narrow curved scales; the scutellum also is clothed with similar scales. The general coloration is greyish brown; there is a distinct white spot at the apex of the hind tibia, and basal lateral white spots on the abdominal segments.

Dr. A. Ingram has bred $2 Q$ at Bole, Northern Territories, Gold Coast. Previously the species has only been recorded from Madagascar.

12. C. tipuliformis, Theo., Mon. Cul. II, p. 325 (1901).

This, I find, is an older name for the species previously dealt with as $C$. theileri, Theo. Additional synonyms are C. creticus, Theo. (Mon. Cul. III, p. 189, 1903) and C. onderstepoortensis, Theo. (U. South Afr. Dept. Agric., First Rept. Vet. Res., p. 265, 1911). I found the type of C. creticus in a pill-box on the lid of which was written "Culex cretinus, n. sp.," but no locality. There is little doubt that it is only a pale specimen of C. tipuliformis; the leg-markings do not differ in the way indicated in the description, nor, apparently, in any other way. $C$. onderstepoortensis is described as "Related to Culex theileri, but easily told by the pale-scaled head and thorax." The scales of the head and thorax of the type (in the British Museum) are not paler than in typical C. theileri.

The cross-veins of this species are somewhat approximated, and on this account Messrs. Dyar and Knab would place it in Culiseta (= Theobaldia); but the male palpi are of typical Culex structure.

Additional locality : British East Africa. 
13. C. univittatus, Theo., Mon. Cul. II, p. 29 (1901).

Add to synonymy :

Culex perexiguus, Theo., Mon. Cul. III, p. 199 (1903).

Culex goughii, Theo., U. South Afr. Dept. Agric., First Rept. Vet. Res., p. 268 (1911) (o only).

C. goughii is described as "A rather obscure species of fatigans type, but can be easily told in both sexes by the white scaled line on the palpi, which is ventral and very marked in the male." This white-scaled line on the under side of the last two joints of the male palpi is characteristic of the pipiens group of species, and occurs in a modified form in C. univittatus. In every one of 380 males of C. pipiens, C. fatigans, etc., examined by the writer, this character was present and showed no variation. The male type of $C$.goughii is a typical C.pallidocephalus.

Additional localities: Palestine (C. perexiguus); S. Spain, four typical specimens in British Museum (Major P. Fowler, July, 1909); Mauritius; Sudan; Gambia; S. Nigeria ; Gold Coast; N.E. Rhodesia ; Brit. E. Africa ; British Central Africa; Transvaal; Natal. One specimen from Salisbury, S. Rhodesia (G. A. K. Marshall) appears to belong to this species, yet lacks the most striking feature-the tibial stripe. This specimen superficially much resembles Ochlerotatus quasiunivittatus. One or two specimens sent by Dr. Ingram, from the Gold Coast, show traces of a pale band on the proboscis, more especially on the under surface, quite half of which is dull ochreous. This is another point of resemblance to $C$. duttoni, but the two are quite distinct. The larva of C. duttoni has a thick, swollen air-tube, rather like that of a Janthinosoma; while in C. univittatus the air-tube is long and thin, as in most species of Culex.

14. C. pygmaeus, N.-L., Arch. Parasit. X, p. 256 (1906).

"Espèce de petite taille à coloration générale fauve . . . Trompe jaune . . Pattes fauves . . . Abdomen brun, annelé de jaune à la base des segments." The species is a true Culex, and from the above statements would seem to be well distinguished from other African forms, notably by the yellow proboscis.

Abyssinia (Imi, Brumpt).

\section{C. pipiens, L., etc.}

Messrs. Dyar and Knab distinguish several American species in this group by means of the basal parts of the male genitalia. They consider C. fatigans, Wied., to be a synonym of $C$. quinquefasciatus, Say. It is very likely that a careful study of the male genitalia of African specimens would enable one or two forms to be properly separated from $C$. pipiens, but this does not seem possible on external characters. I am inclined to think that C. pallidocephalus (= stoehri) may be distinct from $C$. pipiens ; the thorax is a good deal darker and shows indistinct lines of pale scales, somewhat as in O. dentatus. When I sank this as a variety of $C$.pipiens I had seen only two or three specimens; a number of others have now been received.

C. didieri, N.-L. (Arch. Parasit. X, p. 257, 1906), apparently belongs to the pipiens group.

16. C. decens, Theo., Rept. Liverp. S. Trop. Med., Mem. IV, App. p. vii (1901). Additional locality : Gold Coast. 
17. C. simpsoni, Theo., J. Econ. Biol. I, p. 28 (1905).

Additional locality: British East Africa (Masongoleni, S. A. Neave).

18. C. pruina, Theo., Rept. Liverp. S. Trop. Med., Mem. IV, App. p. viii (1901).

Additional locality: Sierra Leone (Daru, Dr. J. C. Murphy).

20. C. guiarti, Blanch., Les Moustiques, p. 629 (1905).

C. laurenti, Newst. (Ann. Trop. Med., I, p. 24, 1907), is synonymous. The lateral whitish spots on the abdomen are folded inwards, and so not visible till the specimen is carefully examined. The colouring of the femora agrees with that of the type of $C$. guiarti.

Additional localities: S. Nigeria; Nyasaland.

23. C. invidiosus, Theo., Mon. Cul. II, p. 329 (1901).

Additional locality : Nyasaland.

25. C. piliferus, Theo., Mon. Cul. IV, p. 274 (1907).

This is closely allied to the European $C$. geniculatus, Olivier (which probably has nothing to do with $C$. hortensis, Ficalbi), and the North American C. apicalis, Adams. Possibly all three may be varieties of the same species.

26. C. insignis, Carter, Bull. Ent. Res. II, p. 37 (1911).

Additional locality : Lagos (Dr.W. H. Sieger). Usually the fifth abdominal segment has a pale apical band, as well as the second, third and fourth.

\section{Genus Protomelanoconion, Theo.}

$$
\text { Mon. Cul. V, p. } 462 \text { (1910). }
$$

1. P. fuscum, Theo., Mon. Cul. V, p. 463 (1910).

This species, or one extremely similar, occurs in India under the name of Stegomyia brevipalpis, Giles. There are six specimens in the British Museum labelled "Stegomyia brevipalpis, type, G. M. Giles"; of these, three $\bigcirc \bigcirc$ are Steg. microptera, Giles, two more $(Q)$ represent two indeterminable species of Culex, while the sixth, a male, agrees with Giles' description and figure of $S$. brevipalpis. So far as I can see it only differs from $P$. fuscum $0 *$ in having the fore and mid claws (at least the larger one) minutely toothed. Thus this genus must rest entirely on the structure of the male palpi, the apical joint of which is almost as short as in Mansonioides.

\section{Genus Culiciomyia, Theo.}

Mon. Cul. IV, p. 227 (1907).

Trichorhynchus, Theo., J. Bomb. Nat. Hist. Soc. p. 240 (1905), (nec Trichorhynchus, Balbiani, 1887).

Neomelanoconion, Theo., Mon. Cul. IV, p. 514 (1907).

Pectinopalpus, Theo., Ann. Mag. Nat. Hist. (8) V, p. 375 (1910).

The type species of Trichorhynchus ( $T$. fuscus) and of Culiciomyia ( $C$. inornata), are, I find, synonymous. Fortunately, however, Theobald's Trichorhynchus is preoccupied by a genus of Protozoa, and so there is no need to change 
the name of the African species. Although Culiciomyia does not seem to differ structurally from Culex, it is perhaps worth while retaining it as a separate genus, since the group can be fairly easily recognised on scale characters. It should, however, be noticed that in Culex annulirostris (and C. somaliensis and C. microannulatus, both perhaps forms of $C$. annulirostris) the male palpi have a row of white translucent hairs in the same position as the similar scales of Culiciomyia.

1. C. nebulosa, Theo., Rept. Liverp. S. Trop. Med., Mem. IV., App., p. x. (1901).

Culex fragilis, Ludl., J. N. Y. Ent. Soc. p. 142 (1903).

A specimen in the British Museum named Culex fragilis is undoubtedly only C. nebulosa. Hence this species, like B. luteolateralis, extends its range into the Philippine Islands.

\section{Genus Eumelanomyia, Theo.}

\section{Mon. Cul. V, p. 240 (1910).}

Resembles Culex in most essentials ; the male palpi are somewhat shorter than the proboscis, of uniform thinness and almost devoid of long hairs; there is a large area of flat scales over the top of the head. From Culiciomyia this genus can be distinguished by the shorter male palpi, which lack the characteristic row of outstanding scales, and by the more extended flat-scaled area on the head.

1. E. inconspicuosa, Theo., Mon. Cul. V, p. 240 (1910).

A medium-sized blackish species, with small lateral, apical pale spots on the abdominal segments, and a pale venter.

Ashanti; Gold Coast (Bibianaha, Dr. H. G. F. Spurrell); Sierra Leone (Daru, Dr. J. C. Murphy).

\section{Genus Micraëdes, Coq.}

\section{Proc. Ent. Soc. Wash. VII, p. 185 (1905).}

1. M. (?) inconspicuosus, Theo. (Aëdes), Entomologist, XLI, p. 109 (1908).

This is a small brown mosquito, $3 \mathrm{~mm}$. in length, and without close examination might be mistaken for a Uranotaenia or an Ingramia, but the proboscis is not swollen at the tip, the fork-cells are longer, and the lateral vein-scales narrow.

The genus Micraëdes was founded by Coquillett for a single North American species, $M$. bisulcatus, which has the palpi one-third the length of the proboscis in both sexes, and a tooth on one claw of the fore and mid legs of the male. This African species does not quite agree with Coquillett's diagnosis, as the palpi are barely one-sixth the length of the proboscis in both sexes, and all the claws are simple (those on the fore and mid legs of the male being unequal); as, however, the species fits better into Micraëdes than any other genus, I have included it here rather than create a new genus for it on very slight characters.

S. Nigeria (Lagos, Dr. Graham); Congo (Coquilhatville, Dr. A. Yale Massey); Uganda (Capt A. D. Fraser); Transvaal.

Leicester (Stud. Inst. Med. Res., Fed. Malay States, III, iii, p. 184) describes a very similar species as Aëdes malayi, and remarks concerning it, "This genus is 
closely related to Culex and Melanoconion on the one hand and less so to Aioretomyia $[=$ Aëdes.-F.W.E.] amongst the AmdeourinaE. In fact nothing could better shew how unscientific is a classification based on palpi than that genera so closely related as Culex, Melanoconion and Aëdes should be placed in different [sub-] families." These remarks are interesting, though Dr. Leicester has wrongly interpreted the genus Aëdes.

\section{Genus Hodgesia, Theo.}

\section{J. Trop. Med. VII, p. 17 (1904).}

Till recently this genus was only known from females, but Dr. Leicester claims to have found the male of one of the species he describes from Malaya (H. malayi, op. cit. p. 231). He says it is much smaller than the female, but otherwise very difficult to distinguish from it, as the genitalia are almost hidden, the palpi very short (apparently one-jointed), and the antennae pilose as in the female. In both sexes these insects can be distinguished from other CuLICIDAE by the apically dentate wing-scales. There are five species described, two from Africa, two from Malaya and one from the Philippine Is. They are minute black insects with silvery markings on the head, prothoracic lobes and sides and venter of the abdomen.

1. H. sanguinis, Theo. (sanguinae), J. Trop. Med. VII, p. 17 (1904).

Tarsi normal.

Uganda ; Congo ; S. Nigeria.

2. H. cyptopus, Theo. (cuptopous), Mon. Cul. V, p. 545 (1910).

Fourth tarsal joint on fore and mid legs with a tuft of long scales, fifth bent at an angle with the fourth.

Ashanti.

Genus Mimomyia, Theo.

Mon. Cul. III, p. 304 (1903).

Boycia, Newstead, Ann. Trop. Med. I, p. 33 (1907).

Ludlowia, Theo., Mon. Cul. IV, p. 193 (1907).

Megaculex, Theo., Mon. Cul. IV, p. 282 (1907).

Radioculex, Theo., Rec. Ind. Mus. II, p. 295 (1908).

Conopomyia, Leicester, Stud. Inst. Med. Res., Fed. Malay States, III, iii, p. 113 (1908).

Hispidimyia, Theo., Mon. Cul. V, p. 245 (1910).

On examination I found that the single specimen (female) of Mimomyia splendens in the British Museum collection possesses all the characters of Ludlowia, even to the long bristles on the leg, while the remaining species of Mimomyia, Theo., seemed to belong to a quite distinct genus. Subsequent events supported this conclusion, for in a large collection just received by the Entomological Research Committee, from Dr. Ingram of the Gold Coast, is a good series of bred specimens of $M$. splendens, the males having the two-jointed apically swollen palpi characteristic of this genus. As M. splendens is the type species of Mimomyia it becomes necessary to sink Ludlowia 
under Mimomyia, while the new genus Ingramia has had to be erected for those species which were formerly included with $M$. splendens in Mimomyia. To the characters already given (Bull. Ent. Res. II, p. 244, under Ludlowia) may be added the structure of the eighth abdominal tergite in the female. This is narrower and more pointed than in Culex, though not nearly so narrow as in Ochlerotatus, and is of uniform shape throughout the genus (see fig. $1, C$ ). The basal segment of the female antennae is hairy on the inside; the second segment is variable in length, but always longer than the third.

In my previous paper (Bull. Ent. Res., Oct. 1911), reference to Ludlowia sudanensis, Theo., was accidentally omitted; it was described from a single male mounted in balsam, which is said to be, but is not, in the British Museum collection. As the ungues are described as "apparently all equal and simple," its location in this genus must be regarded as doubtful until more material is obtained. Dr. Ingram has performed the remarkable feat of breeding all the African species, except the doubtful $M$. sudanensis. None of the larvae were previously known.

A fresh table of the species is given.

1. Head flat-scaled in middle ; end of hind tarsi not white (sub-genus

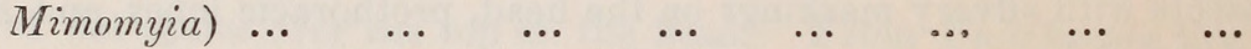

Head not flat-scaled in middle; end of hind tarsi white (sub-genus

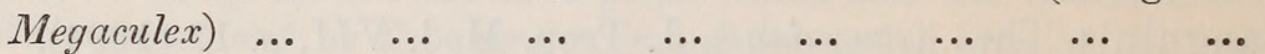

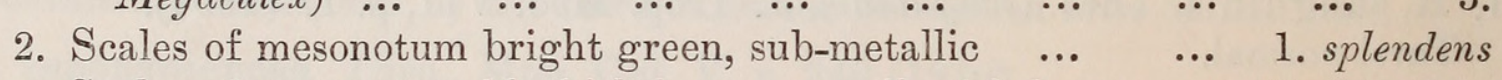
Scales of mesonotum blackish brown or yellowish brown ... \%. hispida.

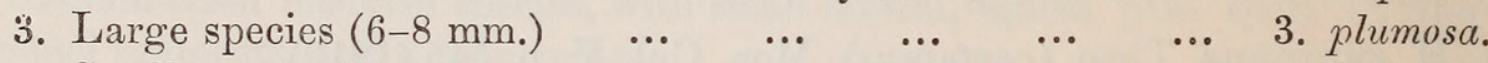
$\begin{array}{lllllllll}\text { Small species }(3-4 \mathrm{~mm} .) & \ldots & \ldots & \ldots & \ldots & \ldots & \ldots & 4 \text {. }\end{array}$

4. Last $2 \frac{1}{3}$ joints of hind tarsi whitish ... $\quad \ldots \quad$... 4 . mimomyiaformis. "Three last hind tarsals pale yellow;" "male ungues all apparently equal and simple" $\quad$.. $\quad \ldots \quad \ldots \quad$... $\quad$ 5. sudanensis.

1. II. splendens, Theo., Mon. Cul. III, p. 304 (1903).

This is one of the most striking and beautiful of all the African CulicidaE; the brilliant green scales contrast strongly with the shiny black integument of the thorax and make it an extremely well-marked species. The legs are mainly golden yellow, but bear numerous purple scales, especially at the tips of the femora, and the apical fourth of the hind tibiae is conspicuously black and somewhat swollen. There are traces of basal pale bands on some of the joints of the tarsi, which are mainly brownish. Length $3 \mathrm{~mm}$., without the proboscis. Second joint of female antennae $1 \frac{1}{2}$ times as long as third.

Uganda; Sudan ; Gold Coast.

2. M. hispida, Theo. (Hispidimyia), Mon. Cul. V, p. 245 (1910).

Ludlowia hispida, Edw., Bull. Ent. Res. II, p. 245 (1911).

Megaculex palustris, Theo., Novae Culicidae, I, p. 13 (1911).

This is a variable species, and it is possible that there may be two or more included under the same name, but I do not think so. The abdomen may be all purple, entirely unbanded, or with distinct basal lateral spots, or with entire basal yellow bands. That these are not specific differences is shown by the fact that 
in Dr. Ingram's series bred from the same lot of larvae one specimen has a banded abdomen, the rest showing only the lateral spots to a variable extent. Usually the second joint of the female antennae is $2 \frac{1}{2}$ times as long as the third (M. hispida, type), but in some specimens quite three times as long (M. palustris, type). The mesonotum is usually clothed with blackish brown scales and black bristles, but the bristles are sometimes yellow and the dark scales seem replaceable by yellowish ones. The metanotum may be all yellowish, or with a dark line down the middle ( $M$. hispida, type), or entirely dark ( $M$. palustris, type).

Uganda; Sudan; Gold Coast.

3. II. plumosa, Theo. (Culex), Mon. Cul. I, p. 373 (1901).

Megaculex albitarsis, Theo., Mon. Cul. II, p. 25 (1901).

Ludlowia plumosa, Edw., Bull. Ent. Res. II, p. 245 (1911).

Second segment of female antennae $2 \frac{1}{2}$ or 3 times as long as third.

S. Nigeria; Gold Coast; Congo ; Uganda; Mashonaland.

4. M. mimomyiaformis, Newst. (Boycia), Ann. Trop. Med. I, p. 34 (1907).

Megaculex pincerna, Graham, Ann. Mag. Nat. Hist. (8) V, p. 267 (1910).

Ludlowia pincerna, Edw., Bull. Ent. Res. II, p. 245 (1.911).

On comparing the types of $B$. mimomyiaformis and $M$. pincerna $I$ find them to be the same. The former has only the last $2 \frac{1}{3}$ joints of the hind tarsi pale, and the pale spots on the tarsal articulations are present though faint.

Second joint of female antennae $1 \frac{1}{3}$ times the length of the third, and rather swollen.

N. and S. Nigeria ; Gold Coast ; Congo.

5. II. sudanensis, Theo. (Ludlowia), Mon. Cul. IV, p. 195 (1907).

I rather strongly suspect that this is really the same as the last species; in any case the claws are probably not "all equal and simple." One specimen in Dr. Ingram's series of $M$. hispida shows the $O^{\top}$ palpi bent exactly as figured by Theobald (First Rept. Wellc. Lab. p. 83, where the species was not named), and this condition is evidently only due to shrinkage.

Sudan.

\section{Genus Uranotaenra, Arribalzaga.}

Rev. Mus. La Plata II, p. 163 (1891).

Pseudouranotaenia, Theo., J. Econ. Biol. I, p. 33 (1905).

Anisocheleomyia, Theo., Entomologist, XXXVIII, p. 52 (1905).

Pseudoficalbia, Theo., U. South Afr. Dept. Agric., First Rept. Vet. Res., p. 272 (1911) (nom. nud.) ; id., Trans. Linn. Soc. Lond. XV, 1, p. 89 (1912).

This genus is quite an easy one to recognise. The most marked feature is found in the short fork-cells, the first being slightly or considerably shorter than the second. The head is always flat-scaled, and also the scutellum; the proboscis is slightly swollen at the tip in the female, distinctly so in the male; the middle femora are swollen near the base (but this is the case in many other mosquitos) The species are all small $(2-3 \mathrm{~mm}$. in length) and frequently have blue markings on 
the head and thorax, the blue in some species being replaceable by whitish, probably owing to fading after death. The thorax is short and rounded. The claws of the male give another marked generic character, which will at once distinguish Uranotaenia from all other Culicidas. On the front legs the claws are small and equal in length, though the inner one is often broader than the outer ; on the mid legs there is one small and one large claw, the large one falcate; on the hind legs both claws are small and equal. In the second volume of his Monograph, Theobald gives figures which purport to be the claws of the front legs of $U$. annulata (p. 251), U. mashonaensis (pp. 260, 261) and $U$. alba (p. 262). In each case, as I have proved by examining the types, these figures portray not the front but the middle claws of the male. Again, Theobald states (Mon. Cul. IV, p. 565) that the fore ungues of $U$.geometrica are unequal; this also is incorrect. All the claws are simple in both sexes. The fore claws of the female are sometimes (? always) like those of the male-one being broad, and it was on account of this circumstance that Theobald introduced the genus Anisocheleomyia. In all his three species ( $A$. nivipes, $A$. alboannulata and $A$. leucoptera), each of which was described as from one or two males, the types are in reality females.

\section{Table of the species.}

1. Thorax with a whitish or blue line in front of the base of the wings

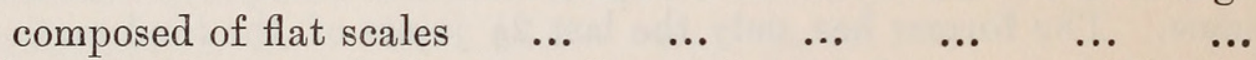

Thorax without such line: no flat scales on mesonotum (Pseudo$\begin{array}{llllllllll}\text { ficalbia, Theo.) } \quad \ldots & \ldots & \ldots & \ldots & \ldots & \ldots & \ldots & 10 .\end{array}$

2. Hind tarsi with distinct whitish bands, last two joints white $\quad \ldots \quad 3$. $\begin{array}{lllllllll}\text { Hind tarsi unbanded } & \ldots & \ldots & \ldots & \ldots & \ldots & \ldots & \ldots & 4 .\end{array}$

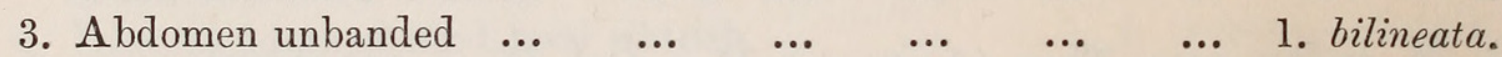
Abdomen with basal yellowish bands on all the segments... 2. connali.

4. Some at least of the abdominal segments bearing distinct pale bands

Abdomen unbanded, though there may be small pale apical lateral

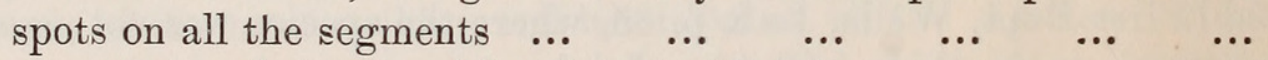

5. Segments 2 and 4 only with pale apical bands $\quad \ldots \quad \quad \ldots \quad 3$. alba.

Segments 1-4 pale apically, or entirely pale $\quad \ldots . \quad \ldots \quad \ldots 6 \quad 6$.

6. Segments 6 and 7 with pale basal bands; 1-4 nearly all palescaled

4. alboabdominalis.

Segments 6 and 7 with pale apical lateral patches; a white line on

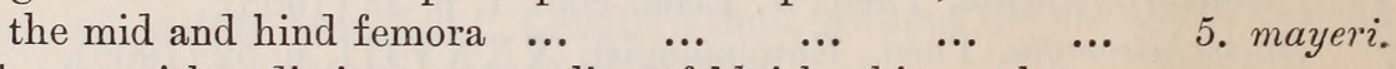

7. Pleurae with a distinct narrow line of bluish white scales

1. bilineata var. fraseri.

Pleurae without such line

8. Median area of head with black scales; male legs normal ... 8 .

9. A bluish median line on the posterior half of the mesonotum; legs of male very peculiar, the metatarsus on the anterior pairs being shorter than the following joint $\quad \ldots \quad \ldots \quad \ldots \quad \ldots \quad$ 7. pallidocephala. No median bluish line on thorax (1 o only known) 8. coeruleocephala. 
10. Lower half of pleurae pale yellowish, sharply contrasting with upper half and mesonotum, which are deep brown; hind tarsi with the last two joints whitish $\quad \begin{array}{llllll} & \ldots & \ldots & \ldots & \ldots & \ldots\end{array}$

Integument of pleurae more or less unicolorous, and not contrasting with the mesonotum ; hind tarsi all dark

11. Head scales light brown; white rings embracing the articulations of the first, second and third joints of the hind tarsus

9. annulata.

Head scales dark brown, no pale rings on basal joints of hind tarsi

10. candidipes.

12. Mesonotum all brown or dark brown

$\begin{array}{ccc}\cdots & \cdots & \cdots\end{array} \quad \cdots$

Mesonotum at least partly yellow; pleurae yellow, sharply con-
trasting with the black legs ; head scales all deep black

13. A spot of flat blue scales on the pleurae; similar scales on the

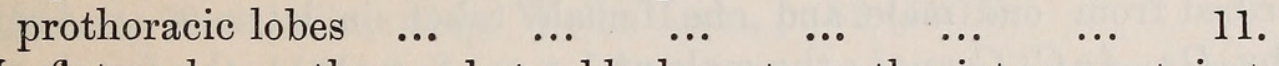

No flat scales on thorax, but a black spot on the integument just in front of each wing base $\quad \ldots \quad \ldots \quad \ldots \quad$... mashonaensis.

14. Posterior half of mesonotum mainly brown $\quad \ldots \quad \ldots \quad$ 13. ornata. Posterior half of mesonotum mainly yellow ... $\quad \ldots \quad \ldots$ 14. nigripes.

1. U. bilineata, Theo., Mon. Cul. V, p. 517 (1910).

This is a very distinct species, being, with $U$. connali, the only African species with a white line on the pleurae and banded hind tarsi. $U$. connali, indeed, may eventually prove to be only a well-marked variety of $U$. bilineata, but as the material is so scanty it is described provisionally as distinct. Both have the first longitudinal vein clothed with white scales to the middle, a character possessed by none of the other species.

$U$. bilineata, var. fraseri, nov. Two females from Mpumu Forest, Uganda (Capt. A. D. Fraser), were at first thought to represent a distinct species, as the legs appeared to be unbanded, and there are faint traces of basal pale bands on the fifth, sixth and seventh abdominal segments. However, a close examination in a good light revealed traces of the same leg-banding as is present in $U$. bilineata, and as these specimens are quite typical in other respects, they must be regarded as only a variety of the present species. Specimens of the typical form have been received from the same place.

Ashanti ; Uganda.

\section{U. connali, sp. n.}

$\delta^{\top}$. Head clothed with dark, fuscous brown, flat scales in the middle, with a rather narrow margin of whitish blue flat scales; two or three very long, whitish blue scales project over the front; a row of black upright forked scales round the edge of the dark area, and a few more on the nape. Proboscis, palpi and antennae brown. Thorax: mesonotum dark reddish brown, clothed with dark brown scales, those on the scutellum flat; a row of large flat bluish white scales extending forwards from the wing-base for half the length of the thorax ; pleurae dark brown, with a median longitudinal line of flat bluish white scales; this line extends across the prothoracic lobes; a few similar scales above the bases of the coxae. The integument bordering both these lines is darkened. Metanotum 
dark reddish brown. Wings with brown-scaled veins, except the first longitudinal, which is clothed with white scales as far as the middle of the wing. First forkcell two-thirds as long as second. Halteres with a dark brown knob, stem paler. Legs dark brown, femora paler beneath. Fore and mid legs with faint indications of pale spots on the articulations; hind legs with a yellowish knee-spot; distinct yellowish bands at the apex of the tibia and on the articulations of the first three tarsal joints ; the apex of the third and the whole of the fourth and fifth tarsal joints yellowish. Claws of typical Uranotaenia structure. Abdomen dark brown, with yellowish basal bands, broadening out in the middle, on all the segments; seventh segment with a whitish apical lateral spot; venter pale ochreous. Length $2.5 \mathrm{~mm}$., without the proboscis.

Types in the British Museum (presented by the Entomological Research Committee).

Described from one male and one female taken in latrines at Accra, Gold Coast, by Dr. A. C. Connal; the male at 1 p.m., 2. v. 1911, the female at 8 a.m., 23. iv. 1911.

Closely allied to $U$. bilineata; distinguished by the presence of pale bands on the abdomen.

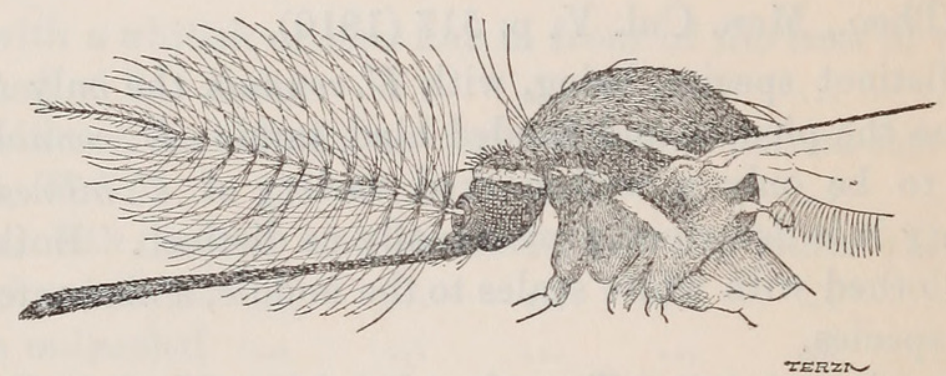

Fig. 6.-Uranotaenia connali, sp. n. Head and thorax of male.

3. U. alba, Theo., Mon. Cul. III, p. 303 (1903).

U. mashonaensis, var. alba, Theo., Mon. Cul. II, p. 262 (1901).

Known only from a single male, which differs from the following in the markings of its abdomen. The sixth and seventh segments are unbanded; the second and fourth with pale apical patches. It is only provisionally regarded as a distinct species from $U$. alboabdominalis. The specimen is much rubbed.

S. Rhodesia.

4. U. alboabdominalis, Theo., Mon. Cul. V, p. 508 (1910).

The first longitudinal vein is white-scaled at the base. In the types the head is entirely blue-scaled, and the four basal segments of the abdomen are entirely whitish, but in some specimens from Uganda the head is black-scaled in the middle, and the first four abdominal segments have only apical whitish bands.

Sudan; Uganda.

5. U. mayeri, sp. n.

O. Head as in $U$. connali, but the pale margin narrower. Thorax as in $U$. connali. Wings with brown-scaled veins; extreme base of the fourth and a short space of the fifth vein clothed with white scales. Halteres light ochreous 
brown, knob dark brown. Legs dark brown, femora lighter beneath; mid and hind femora with a line of white scales in front; tips of hind femur and tibia black. Abdomen dark brown, segments 1-4 with median, $5-7$ with lateral apical whitish patches; venter not visible. Length $2.5 \mathrm{~mm}$., without proboscis.

Type in the British Museum (presented by the Entomological Research Committee).

Described from two females: Type, taken in house, 8. x. 1910, at Oshogbo, S. Nigeria (Dr. T. F. G. Mayer); a second specimen from Accra, Gold Coast (Dr. A. C. Connal), taken in latrine, 7 a.m., 6. v. 1911.

Differs from $U$. alboabdominalis in the presence of a white line on the mid and hind femora, and in the absence of basal pale bands on the sixth and seventh abdominal segments.

6. U. balfouri, Theo., First Rep. Wellc. Lab., p. 82 (1905).

The smallest species of the genus in Africa, measuring only $2 \mathrm{~mm}$. in length. The abdominal segments have pale apical lateral spots, more distinct in some specimens than in others. As in the two following species, the fifth (not fourth) longitudinal vein is white-scaled towards the base.

Sudan; Gambia ; S. Nigeria; Gold Coast.

7. U. pallidocephala, Theo., Third Rep. Wellc. Lab., p. 266 (1908).

Uranotaenia pallidocephala var. coerulea, Theo., l.c., p. 267.

" similis, Theo., l.c., p. 257 (nom. nud.).

" abnormalis, Theo., Mon. Cul. V, p. 512 (1910).

This species is remarkably distinct in the male sex, on account of the most extraordinary structure of the legs, which has been well described and figured by Theobald (Mon. Cul. V, pp. 512-516). It is strange that he overlooked these peculiarities in the male of $U$.pallidocephala, for the type male of that species is indistinguishable from $U$. abnormalis. In the Uganda specimens the median posterior pale line of the thorax is sometimes indistinct. The claws are quite normal.

Sudan; Uganda.

8. U. coeruleocephala, Theo., Mon. Cul. II, p. 256 (1901).

This species is represented in the British Museum collection by a single female (type). The male described by Theobald (Mon. Cul. III, p. 302) as the male of this species is really $U$. balfouri. $U$. coeruleocephala seems very near $U$. pallidocephala, and it would be interesting to know if the male has the same peculiarities ; if so, the two could hardly be regarded as distinct species.

S. Nigeria. Theobald also records it from Uganda.

\section{U. annulata, Theo., Mon. Cul. II, p. 250 (1901).}

Uranotaenia apicotaeniata, Theo., Mon. Cul. V, p. 520 (1910).

This species is sharply distinguished from all the others by the character given in the key, the dark upper half of the pleurae being concolorous with the integument of the mesonotum. In describing $U$. apicotaeniata Theobald did not notice 
that the pleurae were partly dark, but this is the case in the types. There are no white scales on the wing-veins.

Gambia; S. Nigeria; Ashanti.

10. U. candidipes, nom. n.

$U$. nivipous, Theo., Entomologist XLV, p. 93 (1912),-nec U. (Anisocheleomyia) nivipes, Theo., Entomologist, XXXVIII, p. 53 (1905).

" . Head deep brown, with golden forked scales; palpi and proboscis deep brown. Thorax rich brown, with long dark chaetae, pleurae pale ochreous ; scutellum dusky brown, with dark border bristles. Abdomen black, with apical creamy median areas, venter pale creamy white. Legs deep brown, pale at the base, last two hind tarsi and most of the third creamy white ; the last tarsals of the other legs show pale reflections. Wings with normal venation, but in certain lights subcostal, second, and fourth veins show brilliant violet reflections under the microscope. Length $4 \mathrm{~mm}$.

"Habitat.-Onderstepoort, Transvaal.

"Observations.-Described from a single perfect female sent me by Dr. Theiler. It comes nearest Uranotaenia apicotaeniata, Theob., but can at once be told by the dark scaled head and the absence of pale apical bands on the first, second and third hind tarsals, and on the second tarsals of the fore and mid legs" (Theobald).

11. U. fusca, Theo., Mon. Cul. IV, p. 584 (1907).

Ficalbia inornata, Theo., Entomologist, XLI, p. 108 (1908).

nec Uranotaenia fusca, Leic., Stud. Inst. Med. Res., Fed. Malay States, III, iii, p. 227 (1908).

From the descriptions and from what is left of the types, there seems to be no character by which $F$. inornata can be distinguished from $U$. fusca. The types have apparently always been in very bad condition. A good series of this species has recently been received at the British Museum from Uganda (Capt. A. D. Fraser). The spot of blue scales on the pleurae is quite conspicuous, and so are the blue prothoracic lobes. The abdomen is uniformly deep blackish brown above, the venter uniformly whitish ochreous. The first fork-cell is longer than usual in this genus, but still distinctly shorter than the second. The male claws are quite normal : the inner one on the front feet is much thickened in both sexes, and in the female this is also the case on the mid tarsi.

Uganda; Sierra Leone; Transvaal.

12. U. mashonaensis, Theo., Mon. Cul. II, p. 259 (1901).

Mimomyia mashonaensis, Theo., Mon. Cul. III, p. 306 (1903).

Uranotaenia bimaculata, Theo., Mon. Cul. V, p. 522 (1910).

Theobald gave no reason for transferring this species to Mimomyia, to which genus it certainly does not belong, being an almost typical Uranotaenia. The first fork-cell is rather longer than in most Uranotaenia, this character being shared by $U$. annulata, ? $U$. candidipes, $U$. fusca, $U$. ornata, and $U$. nigripes. It is noticeable that these six species are also abnormal in having no flat blue scales on the mesonotum. In his new genus Pseudoficalbia, Theobald includes $U$. fusca (as $F$. inornata) and $U$. nigripes (which he has re-described from the Seychelles under two new specific names), and so Pseudoficalbia may be taken as applying to this section of Uranotaenia, though in the present writer's opinion the name 
should not be retained even as a subgenus, as there seems no important structural character to distinguish these species from the rest.

Leicester (l.c. p. 226) describes a very similar, but probably distinct species as U. bimaculata; in this the black spots on the mesonotum are, he says, due to patches of black scales.

Uganda ; Ashanti ; Gold Coast; S. Nigeria; S. Rhodesia.

13. U. ornata, Theo., Mon. Cul. V, p. 521 (1910).

One $Q$ from Mpumu, July, 1910 (Capt. A. D. Fraser) seems to belong to this species, but the thorax is rather yellower and to some extent approaches the following species.

Ashanti ( ठ゚); Uganda ( 우).

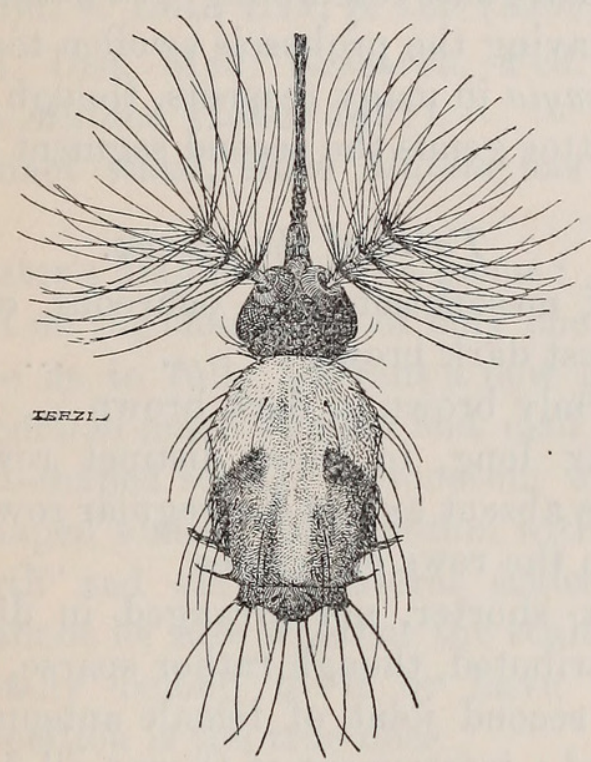

Fig. 7.-Uranotaenia ornata, Theo. Head and thorax of male.

14. U. nigripes, Theo., (Ficalbia), Ann. Mag. Nat. Hist. (7) XV, p. 199 (1905). Pseudoficalbia nigripes, Theo., Trans. Linn. Soc. Lond. XV, 1, p. 89 (1912). Pseudoficalbia pandani, Theo., op. cit. p. 90.

Pseudoficalbia nepenthes, Theo., op. cit. p. 92.

Sierra Leone ; Seychelles Is.

It is doubtful if Leicester's $U$. lutescens (l.c. p. 222) from Malaya is distinct from $U$. nigripes.

Genus Ingramia, nom. nov.

Mimomyia, Theo., Mon. Cul. III, p. 304 (1903) (part).

Dasymyia, Leic., Stud. Inst. Med. Res., Fed. Malay States, III, iii, p. 102 (1908) (nec Dasymyia, Egger, 1858).

It is with great reluctance that a new generic name is introduced into a family which is already so overburdened with names, but in this case the procedure seems unavoidable. As already pointed out, the type species of Theobald's Mimomyia is generically distinct from the other members, and is in fact a Ludlowia. Leicester's Dasymyia is certainly applicable to the species erroneously placed in Mimomyia, as the only important difference between them and his $D$. fusca seems to be that in the latter the larger claw on the fore and mid legs of the male is toothed. Unfortunately, however, Dasymyia is preoccupied in 
Diptera by a genus of Egger's, and thus it is necessary to coin a new name. It is with much pleasure that I name the genus after Dr. A. Ingram, who has done such excellent work in breeding many African CULICIDAE, and is the first to have reared any member of this genus from the larva. I take this opportunity of redefining the genotype, making it Mimomyia malfeyti, Newstead, the species which has been bred by Dr. Ingram.

Most of the characters will be gathered from the table, but the following may be added: Proboscis of male with the apical half much swollen, of female less swollen and then only at the tip; second segment of female antennae at least twice as long as the third; lateral vein-scales rather broad or very broad. In the African species the male claws are all simple.

Ingramia consists of small gnats resembling Uranotaenia in general appearance, and also structurally, in having the proboscis swollen towards the tip. The genus differs widely from Mimomyia in many respects, though it is curious to note that in some species of the latter genus the second segment of the female antennae is elongated.

\section{Table of the species.}

1. Anterior third of mesonotum pale ochreous, concolorous with the pleurae, the rest dark brown $\quad \ldots \quad \ldots \quad \ldots \quad \ldots \quad 1$. circumtestacea.

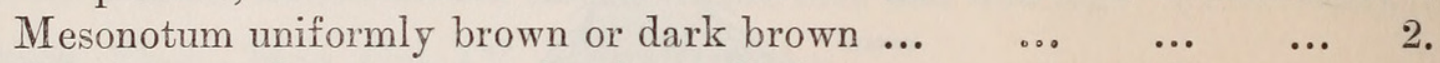

2. Bristles of thorax long, in three distinct rows, the median one double ; scales absent except for regular rows of minute ochreous scales between the rows of bristles $\quad \ldots \quad \ldots \quad \ldots 2$. malfeyti.

Bristles of thorax shorter, not arranged in distinct rows; scales uniformly distributed, though rather sparse, blackish $\quad . . \quad \ldots \quad$.. 3 .

3. Darker species; second joint of female antennae almost five times as long as third; integument of thorax all dark... $\quad . . \quad 3$. nigra.

Paler species; second joint of female antennae hardly more than three times as long as third; three darker patches on thoracic integument...

4. uniformis.

1. I. circumtestacea, Theo. (Mimomyia), Third Rept. Wellc. Lab. p. 264 (1908). Second joint of female antennae about five times as long as third. Sudan.

2. I. malfeyti, Newstead (Mimomyia), Ann. Trop. Med. I, p. 29 (1907).

Easily distinguished by the peculiar arrangement of the vestiture of the thorax. Second joint of female antennae only twice as long as third. The male and female recorded from the Congo by Theobald (Mon. Cul. IV, p. 582) as M. uniformis are this species.

Congo ; Gold Coast.

3. I. nigra, Theo., Mon. Cul. II, p. 237 (1901).

Aedes niger, Theo., l.c.

Verrallina nigra, Theo., Mon. Cul. III, p. 295 (1903).

Mimomyia africana, Newstead, Ann. Trop. Med. I, p. 28 (1907).

" fusca, Theo., Novae Culicidae I, p. 32 (1911).

A distinct row of rather strong black bristles on the pteropleurae. The other three species have only weak, pale-coloured hairs in this position. I. nigra also 
differs from the following in its blackish krown colour and the longer second joint of the female antennae. There is no doubt about the synonymy.

S. Nigeria; Congo; Uganda.

4. I. uniformis, Theo. (Mimomyia), First Rept. Wellc. Lab. p. 80 (1904).

The male type has disappeared from the Museum collection. Front of mesonotum with bluish sub-metallic sheen; brown patches on front of pleurae, iridescent grey when viewed from in front; a median and two posterior longitudinal dark patches on mesonotum, not very distinct.

Sudan; Lado Enclave; Nyasaland (Upper Shire, II, viii, 1911, Prof. $R$. Newstead).

\section{Genus Harpagomyia, Meij.}

Tijd. v. Ent., LII, p. 165 (1909).

Malaya, Leic., Stud. Inst. Med. Research, Fed. Malay States, III, iii, p. 258 (1908) (nec Malaia, Heller 1891).

The name Malaya cannot stand, since Malaia has already been used for a genus of beetles.

The following is Leicester's diagnosis of the genus :

"This genus is founded on the characters of only one specimen, but it is of so remarkable an appearance as to fully warrant a new genus. Proboscis with a distinct joint, the apical portion much swollen and clad with long hairs. Head clothed with large racquet-shaped scales; mesonotum with narrow curved scales; scutellum with racquet-shaped scales. Metanotum with scales (?). Wings with fork-cells moderate length and clavate lateral scales. Malaya genurostris." Leicester remarks, "I cannot be sure whether the scales seen on the mesonotum [meaning metanotum] really belong to it or have been knocked on to it." Doubtless the latter supposition is the true one.

Mr. Carter first suggested to me that this genus was probably the same as Harpagomyia, and he is certainly correct. Leicester mentions the elongated clypeus in his description of the species.

Miss Ludlow (Psyche, XVIII, p. 132, 1911) raises this genus to subfamily rank, on account of the non-development of the biting parts of the proboscis, and (without giving any reason for so doing) associates with it Hodgesia, a bloodsucking genus.

Two African species have been described.

1. H. trichorostris, Theo., Mon. Cul. V, p. 548 (1910).

A median line of flat, bluish silvery scales on the mesonotum; proboscis almost all dark.

Ashanti.

2. H. taeniarostris, Theo., Novae Culicidae, I, p. 34 (1911).

No median line of flat scales on the thorax. Proboscis of the type specimen with the basal half pale, but in two other specimens it is almost all dark.

Uganda.

\section{Tribe Sabethini.}

Metanotum bearing a tuft of long bristles near its posterior end. Anal segment of larva without median ventral brush. 
This group is represented in Africa by a single endemic genus, Eretmopodites. Theobald, indeed, describes two African species of Dendromyia, but these have no bristles on the metanotum, and consequently cannot be included in the Sabethini. They are here placed in Stegomyia.

It may be doubted whether this is really a natural group, as the presence of bristles on the metanotum does not seem to be quite constant.

Genus Eretmopodites, Theo. (emend).

Eretmapodites, Theo., Mon. Cul. I, p. 280 (1901).

Eyes very widely separated; prothoracic lobes rather small and widely separated; proboscis slender throughout, shorter than abdomen; clypeus bare; palpi of male thin, acuminate, nearly as long as proboscis ; palpi of female short; fore and mid claws of female toothed; chaetae of metanotum rather short.

All the species have the head clothed with flat metallic silvery scales; the dorsum of the abdomen is black with a row of lateral silver patches, the venter uniformly golden yellow.

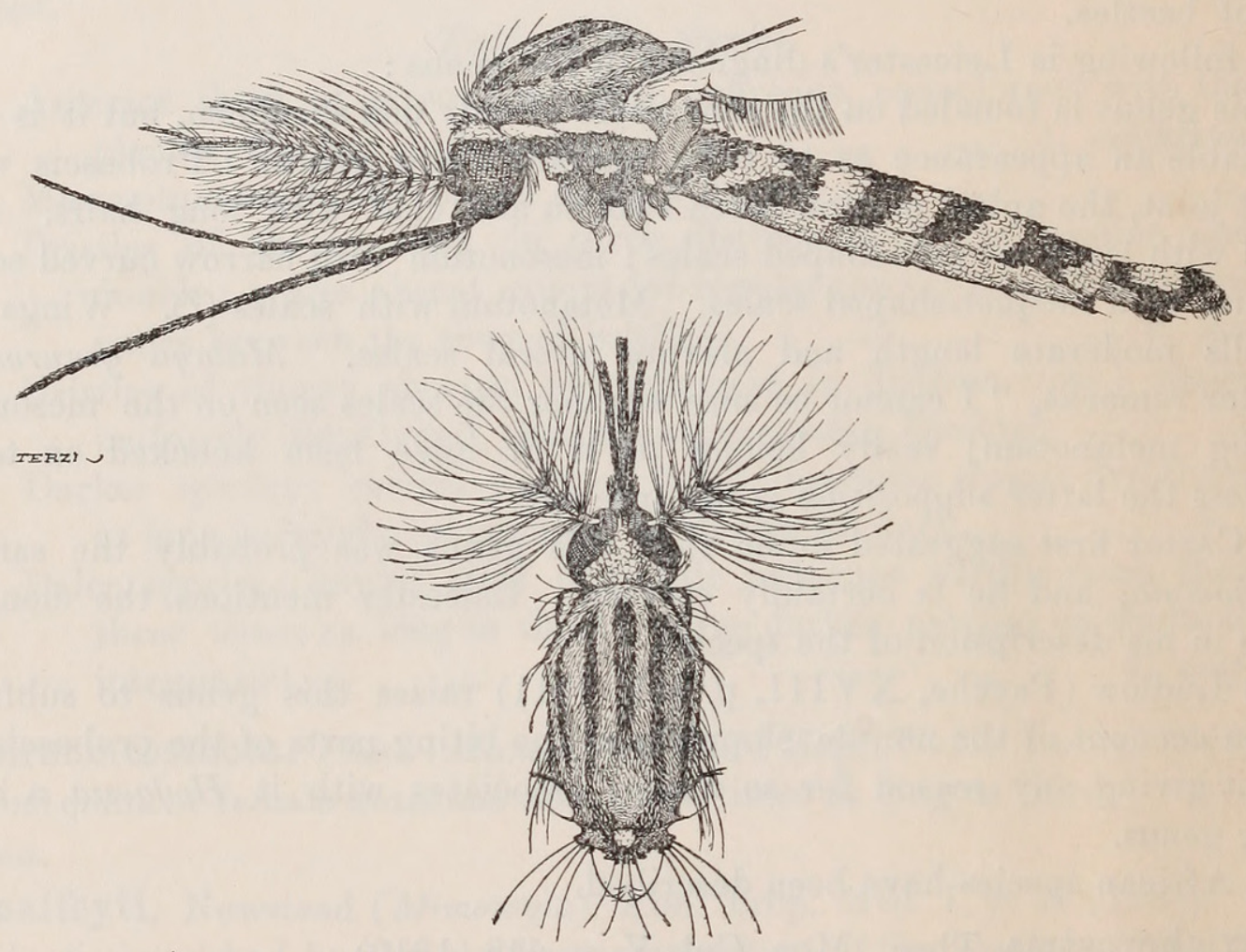

Fig. 8.-Eretmopodites quinquevittatus, Theo., male. Side view of insect, and head and thorax from above.

Leicester's Chaetomyia is probably related to Eretmopodites, but has the palpi more than half the length of the proboscis in the female. Eretmopodites is analogous to Desvoidya, Chaetomyia to Leicesteria.

\section{Table of the species.}

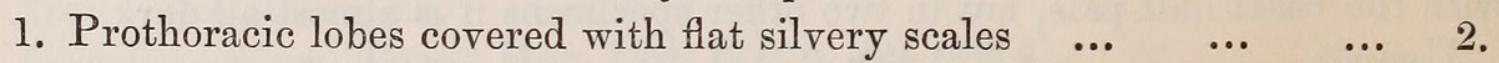

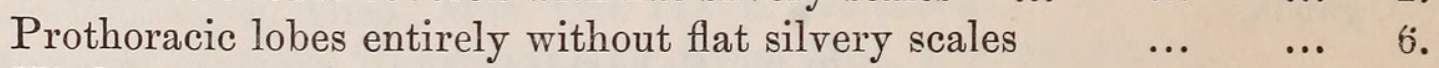

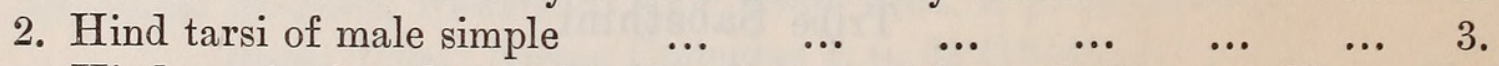
Hind tarsi of male feathered; thorax without distinct markings 


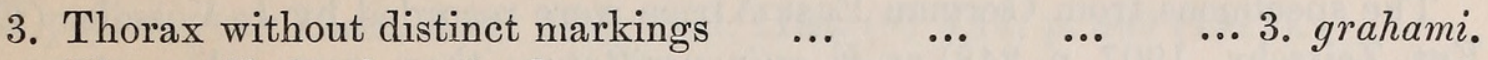
$\begin{array}{llllllll}\text { Thorax distinctly striped } & \ldots & \ldots & \ldots & \ldots & \ldots & \ldots & 4 .\end{array}$

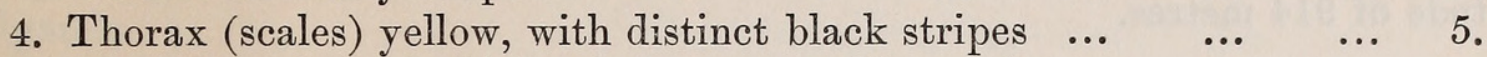
Thorax (scales) blackish, with narrow golden stripes ...2. inornatus.

5. A median black longitudinal stripe on thorax (.. 1. quinquevittatus. No median black longitudinal stripe on thorax $\quad \ldots \quad$... (condei).*

6. Last two joints of hind tarsi white, simple in male $\ldots \quad$... 5. leucopus. Last two joints of hind tarsi not white, tufted in male 6. oedipodius.

1. E. quinquevittatus, Theo., Mon. Cul. I, p. 280 (1901) ( $Q$ only).

E. austenii, Theo., Mon. Cul. V, p. 572 (1910).

The original description of $\boldsymbol{E}$. quinquevittatus was composite, applying to the male of one species and the female of another (vide Ann. Mag. Nat. Hist., July, 1911, pp. 67-73).

The majority of the British Museum specimens of $E$. quinquevittatus (and $E$. condei) show no sign of chaetae on the metanotum, and do not appear ever to have possessed them. In one or two individuals, however, they are present, and also in all the other members of the genus.

Sierra Leone; Ashanti; S. Nigeria.

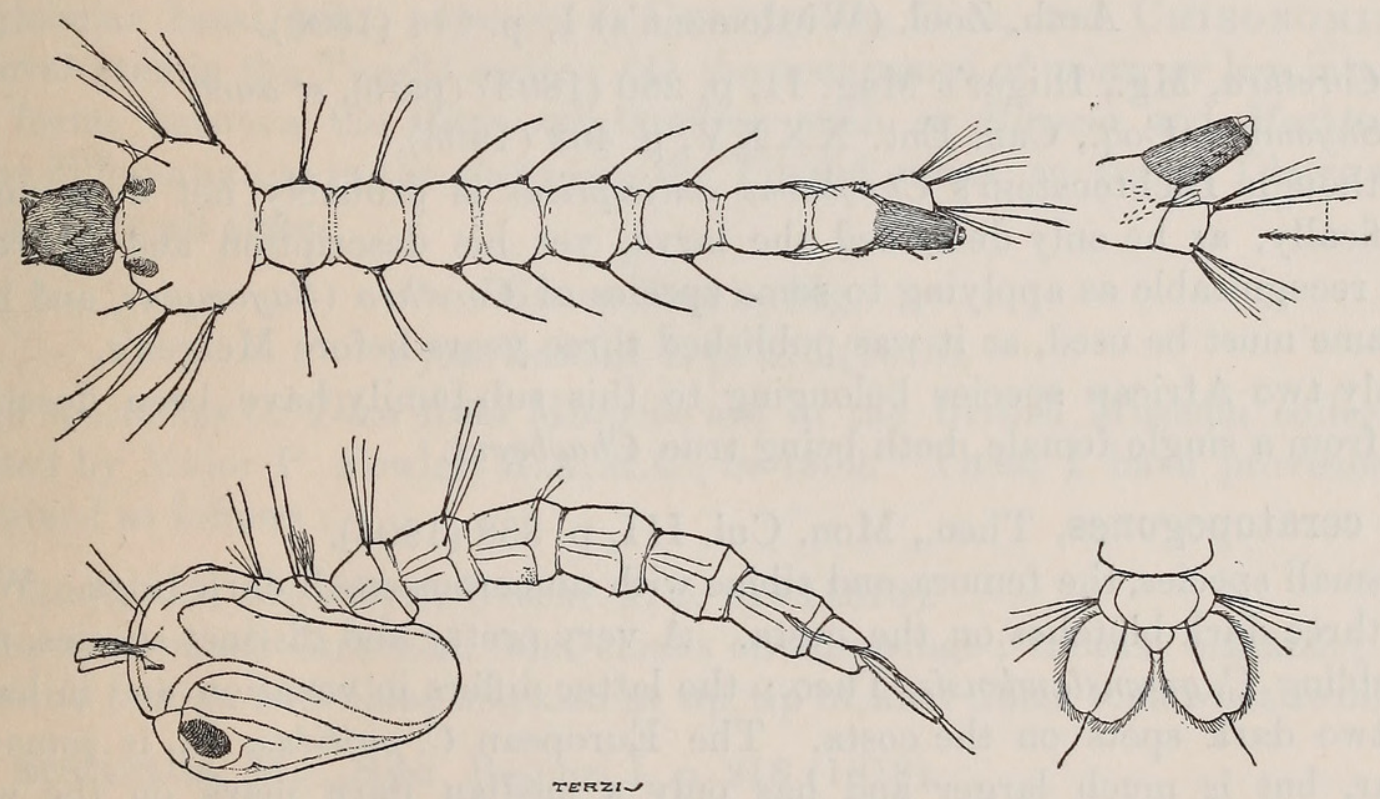

Fig. 9.-Eretmopodites chrysogaster, Graham. Larva from above, and side view of terminal segments ; pupa from side, and dorsal view of terminal segments. Uganda.

2. E. inornatus, Newstead, Ann. Trop. Med. I, p. 12 (1907).

E. melanopous, Graham, Entomologist, XLII, p. 158 (1909).

Sierra Leone; Ashanti ; S. Nigeria ; Congo.

3. E. grahami, Edwards, Ann. Mag. Nat. Hist. (8) VIII, p. 71 (1911). Ashanti.

4. E. chrysogaster, Graham, Entomologist, XLII, p. 157 (1909).

E. quinquevittatus, Theo., l.c. (o only).

Sierra Leone; Ashanti ; Uganda; German E. Africa (?).

* From Madagascar. Possibly only E. quinquevittatus. 
The specimens from German East Africa were recorded by J. Vosseler (Deut. Ent. Zeitschr., 1907, p. 248) as $E$. quinquevittatus; they were taken at an altitude of 914 metres.

5. E. leucopus, Graham (leucopous), Entomologist, XLII, p. 88 (1909).

Ashanti; S. Nigeria (Bende, 1 q taken in dispensary, 5 p.m. 14. v. 1911, Dr. Macdonald).

6. E. oedipodius, Graham (oidipodeios), Entomologist, XLII, p. 86 (1909).

Ashanti ; Gold Coast (Bibianaha, Dr. H. G. F. Spurrell); Uganda (Damba Island, L. Victoria Nyanza, Dr. G. D. H. Carpenter $)$.

\section{Sub-family 2. CHAOBORINAE.}

Proboscis not longer than the head; palpi curled downwards and inwards ; antennae of male plumose, of female verticillate; thorax projecting somewhat over the head; claws equal and simple in both sexes (except Pelorempis); the whole insect hairy, the wings densely so; scales absent (except on the wingfringe and, in Ramcia, on the veins of the wings).

\section{Genus Снаовоrus, Lichtenstein.}

Arch. Zool. (Wiedemann's) I, p. 174 (1800).

Corethra, Mg., Illiger's Mag. II, p. 260 (1803) (part), et auct.

Sayomyia, Coq., Can. Ent. XXXV, p. 402 (1903).

Although Lichtenstein's Chaoborus antisepticus is probably not determinable specifically, as he only described the larva, yet his description and figure are quite recognisable as applying to some species of Corethra (Sayomyia), and hence his name must be used, as it was published three years before Meigen's.

Only two African species belonging to this sub-family have been described, each from a single female, both being true Chaoborus.

1. C. ceratopogones, Theo., Mon. Cul. III, p. 338 (1903).

A small species, the femora and tibiae with numerous small dark rings. Wings with three dark blotches on the costa. A very pretty and distinct species, much resembling $C$. queenslandensis, Theo.; the latter differs in venation and in having only two dark spots on the costa. The European C. pallidus, F., is somewhat similar, but is much larger and has only a median dark mark on the wings extending from the costa over the cross-veins.

Gambia.

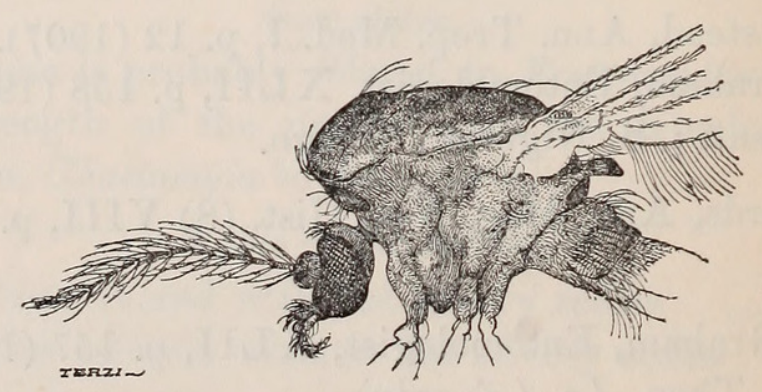

Fig. 10.-Chaoborus pallidipes, Theo. Side view of head and thorax. 
2. C. pallidipes, Theo., Ann. Mag. Nat. Hist. (8) VII, p. 399 (1911).

Legs all pale; wings unspotted; thorax dark above.

Uganda.

\section{Sub-family 3. DIXINAE.}

Whole insect, notably the antennae (in both sexes) and the wings, almost bare ; head and thorax as in CHAOBorinae; neuration of the Culicid type, but differing in some details, principally in the course of the second vein; in the male the claws of the fore and mid legs are larger than those on the hind legs, and bear several long, fine teeth on the under side; in the female the claws are all equal and simple.

That Dixa is related to the Culicidae is now well recognised: Williston favours its inclusion in the family, making three sub-families of CuLICIDAE-as here; Dyar would group Dixa with Chaoborus and its allies into a separate farnily. The inclusion of Dixa with the Culicidae is supported by (1) the structure and habits of the larvae and pupae; these, according to Knab, are subject to much variation in Dixa, but are essentially similar to what is found in the Chaoborinae ; (2) the neuration of the adults, which is of a form found only in Dixa and the Culicidas ; (3) the structure of the adult antennae, with one globular basal joint, cornmon to Culicidae, Dixa, and Chironomidae, but never seen in the Tipulid series ; (4) the occurrence of more or less intermediate forms between the three sub-families, such as Ramcia and Mochlonyx; (5) the differentiation in the claws-in the Tipulid series, so far as I have seen, the claws are all alike.

\section{Genus Dixa, Mg.}

\section{Syst. Beschr. I, p. 216 (1818).}

Two specimens of Dixa from Morocco are in the British Museum collection, collected by Major P. Fowler, R.A.M.C., in 1909. These I have provisionally determined as follows :

1. D. maculata, Mg., Syst. Beschr. I, p. 219 (1818).

Cross-veins much darkened, faint clouds on the wings ; thorax blackish ; legs yellowish ; femora and tibiae blackish at tip, tip of hind tibiae somewhat swollen.

2. D. aestivalis, Mg., Syst. Beschr. I, p. 218 (1818).

Wings clear; thorax reddish; legs all yellowish brown.

\section{List of new names proposed in this paper.}

$\begin{array}{lllllllllllll}\text { Stegomyia fraseri, } \mathrm{sp} . \mathrm{n} . & \ldots & \ldots & \ldots & \ldots & \ldots & \ldots & \ldots & \ldots & \ldots & \ldots & 11\end{array}$

$\begin{array}{llllllllllll}" & \text { metallica, nom. } \mathrm{n} . & \ldots & \ldots & \ldots & \ldots & \ldots & \ldots & \ldots & \ldots & \ldots & 11 \\ & \ldots & \ldots & \ldots & \ldots & \ldots & \ldots & \ldots & \ldots & 12\end{array}$

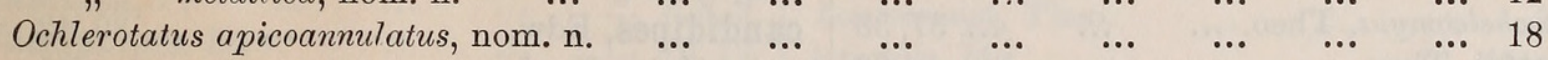

$\begin{array}{lllllllllll}" \quad \text { fascipalpis, sp. n. } & \ldots & \ldots & \ldots & \ldots & \ldots & \ldots & \ldots & \ldots & \ldots & 19\end{array}$

$\begin{array}{llllllllll}\text { Culex ager, Giles, var. n. ethiopicus } & \ldots & \ldots & \ldots & \ldots & \ldots & \ldots & \ldots & \ldots & 30\end{array}$

$\begin{array}{llllllllllll}\text { Uranotaenia connali, } \mathrm{sp} . \mathrm{n} . & \ldots & \ldots & \ldots & \ldots & \ldots & \ldots & \ldots & \ldots & \ldots & 39\end{array}$

$\begin{array}{llllllllllll}" & \text { mayeri, sp. n. } & \ldots & \ldots & \ldots & \ldots & \ldots & \ldots & \ldots & \ldots & \ldots & 40\end{array}$

$\begin{array}{llllllllll}" & \text { bilineata, Theo., var. n. fraseri } & \ldots & \ldots & \ldots & \ldots & \ldots & \ldots & \ldots & 39\end{array}$

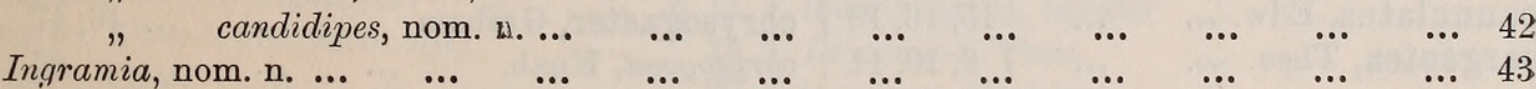




\section{List of proposed emendations.}

\begin{tabular}{|c|c|c|c|c|c|c|c|c|c|}
\hline & & & & & & & & & GE. \\
\hline Loxorhynchates & & T. phytophygus & & (10 & $\cdots$ & ... & ... & $\cdots$ & 3 \\
\hline Aёdomyia & $"$ & Aedeomyia ... & $\ldots$ & $\ldots$ & $\ldots$ & $\ldots$ & $\ldots$ & $\ldots$ & 24 \\
\hline Hodgesia sanguinis & $"$ & H. sanguinae & ... & ... & ... & ... & $\ldots$ & $\ldots$ & 35 \\
\hline " cyptopus & $"$ & H. cuptopous & ... & ... & ... & ... & ... & .. & 35 \\
\hline Eretmopodites & $"$ & Eretmapodites & ... & ... & ... & ... & ... & $\ldots$ & 46 \\
\hline , leucopus & 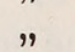 & E. leucopous & $\ldots$ & $\ldots$ & ... & $\ldots$ & ... & ... & 47 \\
\hline oedipodius & $"$ & E. oidipodeios & ... & $\ldots$ & $\ldots$ & $\ldots$ & ... & ... & 47 \\
\hline
\end{tabular}

\section{INDEX.}

[Tabulated African genera and species in heavy type ; synonyms in italics.]

\begin{tabular}{|c|c|c|c|c|c|c|c|}
\hline \multirow{2}{*}{\multicolumn{3}{|c|}{$\begin{array}{l}\text { abnormalis, Theo. (Bathosomyia) } \\
\text { abnormalis, Theo. (Uranotaenia) }\end{array}$}} & $\begin{array}{l}\text { PAGE. } \\
17,22\end{array}$ & \multirow{3}{*}{$\begin{array}{l}\text { apicotaeniata, Theo. } \\
\text { A pornculex, Theo. } \\
\text { argenteopunctatus, }\end{array}$} & & & $\begin{array}{r}\text { PaGe. } \\
\ldots 41,42\end{array}$ \\
\hline & & & $\ldots \quad 41$ & & & & \\
\hline Acartomyia, Theo. & ... & ... & ... & & \multicolumn{3}{|c|}{ Theo. (Aedimor- } \\
\hline edeomyia, Theo. & ... & ... & ... & 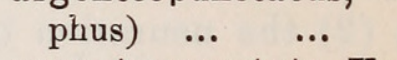 & $\ldots$ & $\ldots$ & $16,20,21$ \\
\hline ides, Mg. ... & ... & ... & 35 & \multicolumn{4}{|c|}{ argenteopunctata, Ventr. (Heptaphle- } \\
\hline edimorphus, Theo. & ... & ... & ... & bomyia) $\quad \ldots$ & $\ldots$ & $\ldots$ & ... 28,31 \\
\hline ia, Theo. & ... & ... & 5,24 & \multicolumn{2}{|c|}{ argenteoventralis, Theo. } & ... & ... \\
\hline Mg. ... & ... & ... & 49 & Armigeres, Theo. & $\ldots$ & ... & ... \\
\hline o. $\quad \cdots$ & $\cdots$ & $\cdots$ & .. & Theo. & ... & ... & ... 2 \\
\hline T.-L. (Aëdon & myia) & $\cdots$ & $\cdots$ & s, Theo. ... & $\cdots$ & $\cdots$ &, 26 \\
\hline wst. (Mir & myi & $\cdots$ & ... & Theo. ... & $\cdots$ & $\cdots$ & $\cdots$ \\
\hline & & $\cdots$ & $\cdots$ & eo. $\quad \ldots$ & $\cdots$ & $\cdots$ & $\cdots$ \\
\hline & & $\cdots$ & $\ldots 7,8,10$ & leo. ... & $\cdots$ & $\cdots$ & ... 3 \\
\hline & W & chus) & & Theo. & $\cdots$ & $\cdots$ & \\
\hline & & & ... 21 & heo. & $\cdots$ & $\cdots$ & \\
\hline & & & & & $\cdots$ & $\cdots$ & \\
\hline$\cdots$ & ... & $\cdots$ & $\ldots 2^{2}$ & ta, Theo. & $\ldots$ & $\ldots$ & 40 \\
\hline & ... & ... & $\ldots 3$ & \multicolumn{3}{|c|}{ bimaculata, Leic. (Uranotaenia) } & ... \\
\hline Icq. & ... & ... & 15 & \multicolumn{3}{|c|}{ bimaculata, Theo. (Uranotaenia) } & ... \\
\hline & $\cdots$ & $\cdots$ & $\ldots$ & bipunctata, Theo. & $\ldots$ & ... & ... 2 \\
\hline is, Thec & & $\cdots$ & $38,40,41$ & oq. ... & ... & ... & ... \\
\hline & niso & eleom & 38 & ewst. $\ldots$ & ... & $\ldots$ & ... \\
\hline & & & .. & brevipalpis, Giles (Stegc & romyia & & $\cdots$ \\
\hline & & & $\cdots$ & \multicolumn{4}{|c|}{ brevipalpis, Theo. (Toxorhynchites) } \\
\hline & $\cdots$ & .. & ... 17, 21 & bromeliae, Theo. ... & $\cdots$ & $\cdots$ & $\cdots$ \\
\hline ewst. & & $\cdots$ & ... 9,12 & L. $\quad \ldots$ & ... & $\cdots$ & $\cdots$ \\
\hline & $\cdots$ & .. & .. 9 & eo. ... & ... & ... & ... 1 \\
\hline . & .. & $\cdots$ & $\cdots$ & oq. ... & $\cdots$ & $\cdots$ & ... \\
\hline & $\cdots$ & $\cdots$ & ... 17, 21 & s, Graham & $\cdots$ & $\cdots$ & ... \\
\hline & $\cdots$ & $\cdots$ & ... 14 & g. $\quad \ldots$ & ... & $\cdots$ & ... \\
\hline yia, Theo. & $\cdots$ & $\cdots$ & ... 37, 38 & dw. & $\cdots$ & $\cdots$ & ... 39,42 \\
\hline & $\cdots$ & .. & $\ddot{0}$ & aab. & $\cdots$ & $\cdots$ & $\cdots$ \\
\hline & $\cdots$ & .. & $38,39,41$ & Theo. & $\cdots$ & $\cdots$ & $\cdots$ \\
\hline & -.. & * & & & ... & $\cdots$ & $\cdots$ \\
\hline & $\cdots$ & •. & & ht. & ... & .. & $\cdots$ \\
\hline & -. & $\cdots$ & $\dddot{m}$ & oeldi & ... & $\cdots$ & $\cdots$ \\
\hline & & *. & 15,16, & & & $\cdots$ & ... \\
\hline apleoargenced, ineo. & ... & ... & $8,10,11$ & chrysogona, Knab. & ... & $\cdots$ & $\cdots$ \\
\hline
\end{tabular}


circumtestacea, Theo... coeruleocephala, Theo. completiva, Leic. condei, Ventr. confusus, Theo. connali, Edw. $\quad \cdots \quad$ Conopomyix, Leic. conradti, Grünb. ... consimilis, Newst. Coquillettidia, Dyar Corethra, Mg. costalis, Lw. creticus, Theo. $\quad \cdots \quad \cdots$ cristatus, Theo. Culex, L. Culicada, Felt. Culicella, Felt. Culicelsa, Felt. $\ldots$ Culiciomyia, Theo. Culiseta, Felt. cumminsi, Theo. cuptopous, Theo. ... cyptopus, Theo.... Danielsia, Theo. Dasymyia, Leic. decens, Theo. Dendromyia, Theo. dentatus, Theo. Desvoidya, Blanch. Diceromyia, Theo. didieri, N.-L. Dixa, $\mathrm{Mg}$. domesticus, Theo. dorsalis, $\mathrm{Mg}$. duỏia, Theo. (Quasistegomyia) dubia, Theo. (Stegomyia)

durbanensis, Theo. duttoni, Theo.

Duttonia, Newst... Ecculex, Felt.

Eretmapodites, Theo. ... Etiorleptiomyia, Theo Etorleptiomyia, Theo. Etorilepidomyia, Alcock Eumelanomyia, Theo. fasciata, F. fascipalpis, Edw. fatigans, Wied. ... Finlaya, Theo. flavus, Ventr. fragilis, Ludl. fraseri, Edw. (Stegomyia) fraseri, Theo. (Chrysoconops) fryeri, Theo.

\begin{tabular}{|c|c|c|c|c|}
\hline GE. & \multirow{2}{*}{\multicolumn{2}{|c|}{ fusca, Leic. (Dasymyia) }} & \multicolumn{2}{|r|}{ PaGe. } \\
\hline 44 & & & ... & ... 43 \\
\hline 8,41 & fusca, Leic. (Uranotaen & & ... & ... 42 \\
\hline 24 & fusca, Theo. (Uranotae & enia) & $\ldots$ & ... 39,42 \\
\hline 47 & Theo. (Mimomyi & & ... & .. 44 \\
\hline 23 & atus, Theo. & & ... & $\ldots$ \\
\hline 8,39 & fuscum, Theo. (Proton & nelan & onion) & $\ldots$ \\
\hline 35 & fuscus, Theo. (Trichorh & hynchus & & $\ldots$ \\
\hline 3 & is, Theo. & $\ldots$ & ... & ... 13,27 \\
\hline 9,30 & Gei & $\ldots$ & ... & $\ldots \quad 14$ \\
\hline 25 & geleb & $\ldots$ & ... & $\ldots$ \\
\hline 48 & & $\ldots$ & $\ldots$ & $\ldots$ \\
\hline 24 & & ... & ... & ... \\
\hline 31 & -S. & $\ldots$ & $\ldots$ & $\ldots$ \\
\hline 26 & eo. $\quad$... & $\ldots$ & ... & ... \\
\hline 5,27 & $i i$, Theo. $\quad \ldots$ & $\ldots$ & $\ldots$ & $\ldots$ \\
\hline 14 & Grabhamia, Theo. & $\ldots$ & ... & $\ldots$ \\
\hline 27 & grahami, Edw. (Eretr & nopodit & & \\
\hline 14 & eo. (Culez & & ... & ... \\
\hline 34 & Blanch & $\ldots$ & $\ldots$ & $\ldots$ \\
\hline 27 & . $\quad \ldots$ & $\ldots$ & $\ldots$ & $\ldots$ \\
\hline 24 & utz $\ldots$ & $\ldots$ & $\ldots$ & ... 14 \\
\hline 35 & ch.... & $\ldots$ & $\ldots$ & .. 29,33 \\
\hline 35 & $a$, Coq. & $\ldots$ & ... & \\
\hline 14 & Will. & $\ldots$ & ... & \\
\hline 43 & ia, Meij. & ... & ... & $\ldots 2,6,45$ \\
\hline 32 & nyia, Theo & & .. & $\ldots \quad 27$ \\
\hline 46 & Heteronycha, Arrib. & ... & ... & $\ldots$ \\
\hline 32 & 1eo. ... & ... & ... & ... 16,20 \\
\hline 7 & & .. & ... & $5,36,37$ \\
\hline 24 & Hispidimyia, Theo. & ... & ... & ... $\quad 35$ \\
\hline 32 & Hodgesia, Theo. & .. & ... & ... 6,45 \\
\hline 49 & hortensis, Fic. $\quad \ldots$ & ... & ... & \\
\hline
\end{tabular}

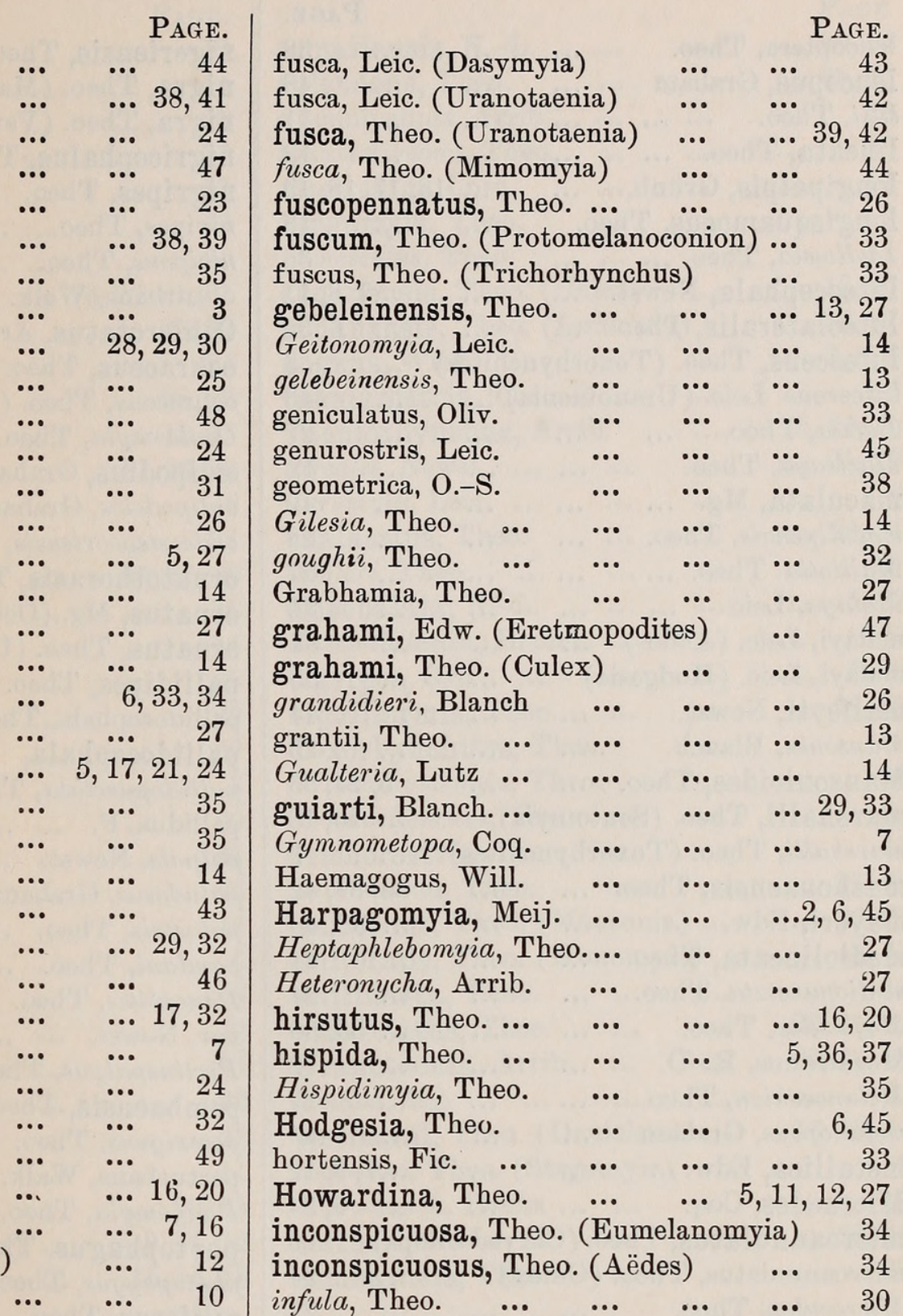

… 16

$28,31,32$

Ingramia, Edw. $\quad \ldots \quad 6,24,34,36,43$ inornata, Theo. (Culiciomyia) ... $\quad$... $\quad 33$ inornata, Theo. (Ficalbia) ... $\quad$... 42 inornatus, Newst. (Eretmopodites) ... 47 insignis, Cart. $\quad \ldots \quad \quad \ldots \quad \quad \ldots \quad \quad \ldots 29,33$ invidiosus, Theo. $\quad \ldots \quad \quad \ldots \quad \quad \ldots 29,33$ irritans, Theo. ... $\quad \ldots \quad \quad \ldots \quad 15,17,23$

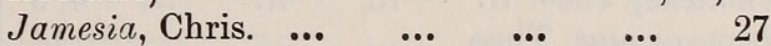

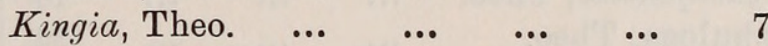
Lasioconops, Theo. $\quad$... $\quad$... $\quad$... $\quad 27$ lateralis, $\mathrm{Mg}$. $\quad \ldots \quad \quad \ldots \quad \ldots \quad \ldots 19,21$ laurenti, Newst. ... $\quad$.. $\quad \ldots \quad$... $\quad$.. 33 Lepidopla'ys, Coq. $\quad$... $\quad \ldots . \quad \ldots \quad 14$ Lepidotomyia, Theo. ... $\quad$... $\quad$... 14 Leslieomyia, Chris. $\quad$... $\quad$... $\quad \ldots . \quad 14$ leucarthrius, Speiser $\quad \ldots \quad$... $\quad \ldots . \quad 17$ $\begin{array}{lllll}\text { Leucomyia, Theo. } & \ldots & \ldots & \ldots & 27\end{array}$

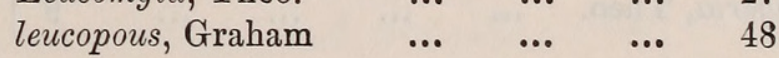




\begin{tabular}{|c|c|c|c|c|c|c|}
\hline & & & & & & AGE. \\
\hline ptera. T & $\cdots$ & $\cdots$ & 38 & nigeriensis, Theo. $\quad \ldots$ & .. & ... 16,20 \\
\hline ucopus, Graham & ... & ... & ... & igra, Theo. (Mansonia). & ... & ... 24 \\
\hline ii, Theo. $\quad$... & ... & $\cdots$ & $\cdots$ & iigra, Theo. (Verrallina) & $\cdots$ & $\cdots \quad 44$ \\
\hline neata, Theo. ... & $\cdots$ & ... & ‥ $\quad 13$ & igricephalus, Theo. ... & $\cdots$ & ... 17,23 \\
\hline ngipalpis, Grünb. & $\cdots$ & ... 16, & $, 17,18,19$ & igripes, Theo. ... & $\cdots$ & $39,42,43$ \\
\hline ongisquamosus, Thec & & $\cdots$ & $\cdots \quad 16$ & ivipes, Theo. .... & $\cdots$ & ... 38,42 \\
\hline udlowia, Theo.... & $\cdots$ & $\cdots$ & ... $\quad 35$ & ivipous, Theo. ... & $\cdots$ & ... 42 \\
\hline Newst. & ... & $\cdots$ & $\ldots 7,8,11$ & oturbans, Walk. & $\ldots$ & $\cdots$ \\
\hline uteolateralis, Theo. & $\ldots$ & ... & $\ldots \quad 6,34$ & Ochlerotatus, Arrib. ... & ... & $4,14,36$ \\
\hline lutescens, Theo. (Toxi & orhyn & hites) & $\ldots \quad 3$ & ochraceus, Theo. (Culex) & ... & ... 17,23 \\
\hline lutescens Leic. (Uranot & taeni & $\ldots$ & ... & ochraceus, Theo. (Chrysoconop & & ... 26 \\
\hline Lutzia, Theo. $\quad \ldots$ & $\cdots$ & ... & $\cdots$ & Oculeomyia, Theo. $\quad$... & $\cdots$ & $\cdots$ \\
\hline heo. & ... & ... & ... & œdipodius, G & .. & ... \\
\hline$\cdots$ & $\cdots$ & $\cdots$ & $\cdots$ & oidipodeios, & ... & ... \\
\hline heo. & ... & ... & ... & onderstepoortensis, Theo. & ... & ... \\
\hline eo. ... & ... & .. & $\cdots$ & s, Theo. ... & ... & $\ldots$ \\
\hline$\ldots$ & ... & $\cdots$ & $\cdots$ & g. (Ochlerotatus) & $\cdots$ & $17,19,21$ \\
\hline ëdes) & $\cdots$ & $\cdots$ & $\cdots$ & ornatus, Theo. (Uranotaenia) & & $\cdots$ \\
\hline Iodgesia & & $\cdots$ & $\cdots$ & leo. $\quad \ldots$ & $\cdots$ & ... 48,49 \\
\hline t. & $\cdots$ & $\cdots$ & $\cdots$ & llidocephala, Theo. (Culex) & $\cdots$ & $\because \quad 32$ \\
\hline ch. & $\cdots$ & $\cdots$ & $\cdots$ & pallidocephala, Theo. (Ura & & lia) 38,41 \\
\hline Theo. & $\cdots$ & $\cdots$ & $5,24,33$ & pallidopunctata, Theo. ... & $\cdots$ & ... $\quad 23$ \\
\hline arshalli, Theo. (Scut & tomyi & & ... 1 & pallidus, F. $\quad \cdots \quad \ldots$ & $\cdots$ & $\cdots$ \\
\hline (Tox & rhyn & ites) & $\cdots$ & palpale, Newst. $\ldots$ & $\cdots$ & $\cdots$ \\
\hline Theo. & $\cdots$ & $\cdots$ & $38,39,42$ & paludosus, Graham & $\cdots$ & $\cdots$ \\
\hline$\ldots$ & $\cdots$ & $\cdots$ & ... 38,40 & palustris, Theo. ... & $\cdots$ & $\ldots 36,37$ \\
\hline Theo. & $\cdots$ & $\cdots$ & $\cdots$ & pandani, Theo. $\ldots$ & $\cdots$ & $\cdots$ \\
\hline heo. & $\cdots$ & $\cdots$ & $\cdots \quad 24$ & Panoplites, Theo. & $\cdots$ & $\cdots$ \\
\hline & $\cdots$ & $\cdots$ & $\ldots 35,36$ & $\cdots$ & $\cdots$ & $\cdots$ \\
\hline & $\cdots$ & $\cdots$ & $\cdots$ & opalpus, Theo. & $\cdots$ & $\cdots$ \\
\hline eo. & $\cdots$ & $\cdots$ & $\cdots$ & $\cdots$ & $\cdots$ & $\cdots$ \\
\hline & $\cdots$ & ... & $\cdots \quad 4$ & $\cdots$ & $\cdots$ & $\cdots$ \\
\hline & $\begin{array}{l}\cdots \\
\cdots\end{array}$ & $\ldots$ & $\ldots 7,9,12$ & $\cdots$ & $\cdots$ & $\cdots 2$ \\
\hline & $\cdots$ & $\cdots$ & $\cdots$ & $\cdots$ & $\cdots$ & $\cdots$ \\
\hline $\mathrm{Th}$ & $(\mathrm{Cul}$ & & & $\cdots$ & $\cdots$ & $\cdots$ \\
\hline & $\ldots$ & $\ldots$ & $\begin{array}{l}\cdots \\
\cdots\end{array}$ & $\begin{array}{l}\cdots \\
\ldots\end{array}$ & $\cdots$ & \\
\hline & $\ldots$ & $\begin{array}{l}\cdots \\
\cdots\end{array}$ & $\begin{array}{l}\cdots \\
\cdots\end{array}$ & eo.... & $\cdots$ & $\cdots 2$ \\
\hline & $\ldots$ & ... & $5,6,35$, & Linn. ... & $\cdots$ & $\cdots$ \\
\hline $\mathrm{Nen}$ & vst. & $\ldots$ & $\begin{array}{l}\ldots .036,37 \\
\ldots 36\end{array}$ & a, Theo. ... & $\begin{array}{l}\cdots \\
\ldots\end{array}$ & $\begin{array}{l}\cdots \\
\cdots\end{array}$ \\
\hline s, Nen & ... & $\ldots$ & $17,21,22$ & $\begin{array}{l}\text { plumosa, Ineo. ... } \\
\text { poicilia, Theo. } \quad \ldots\end{array}$ & $\cdots$ & \\
\hline \& $\mathrm{K}$. & $\ldots$ & $\ldots$ & $\ldots \quad 27$ & pollina, Ineor, Graham & & \\
\hline & $\ldots$ & $\ldots$ & $\ldots$ & poweri, Theo. ... & $\cdots$ & $\ddot{8}, 1$ \\
\hline ... & $\ldots$ & $\ldots$ & 4,6 & Polyleptiomyia, Theo. .... & $\cdots$ & $\ldots$ \\
\hline $\begin{array}{l}\text { o. ... } \\
\text { Theo. }\end{array}$ & $\ldots$ & $\ldots$ & $\ldots$ & Protoculex, Felt. ... & & \\
\hline $\begin{array}{l}\text { Theo. } \\
\text { o. }\end{array}$ & $\ldots$ & $\ldots$ & $\cdots$ & $\begin{array}{l}\text { Protoculex, Feli. ... } \\
\text { Protomacleaya, Theo. }\end{array}$ & $\cdots$ & $\cdots$ \\
\hline & $\ldots$ & $\ldots$ & $\begin{array}{l}\cdots \\
\cdots\end{array}$ & $\begin{array}{l}\text { Protomacleaya, Theo. ... } \\
\text { Protomelanoconion, Theo. }\end{array}$ & $\cdots$ & $\cdots$ \\
\hline & ... & ... & $\cdots$ & $\begin{array}{l}\text { melanoconion, Theo. } \\
\text { Theo. ... ... }\end{array}$ & $\cdots$ & $\begin{array}{rl}\ldots & 5,33 \\
90 & 22\end{array}$ \\
\hline $\begin{array}{l}\text { g. } \\
\text { Theo. }\end{array}$ & ... & $\ldots$ & $\begin{array}{l}\ldots \\
\ldots .\end{array}$ & Pseudoculex, & $\cdots$ & ... 29, 33 \\
\hline $\begin{array}{l}\text { heo. } \\
\text {... }\end{array}$ & ... & ... & $\begin{array}{rr}\ldots & 21,22 \\
\ldots & 27\end{array}$ & $\begin{array}{l}\text { Pseudoculex, } \\
\text { Pseudoficalbic }\end{array}$ & $\cdots$ & $\begin{array}{ll}\cdots & 14 \\
& \end{array}$ \\
\hline $\begin{array}{l}\text { ir. } \ldots \\
\text { ion, Theo. }\end{array}$ & ... & $\ldots$ & $\begin{array}{l}27 \\
33\end{array}$ & $\begin{array}{l}\text { Pseudoficalbi } \\
\text { Pseudograbh }\end{array}$ & $\cdots$ & ... 37, 42 \\
\hline $\begin{array}{l}\text { ion, Theo. } \\
\text { Thieo. }\end{array}$ & & $\cdots$ & 33 & dograbhamia, Theo. & .. & $\cdots$ \\
\hline eo. & $\ldots$ & ... & 14 & heptaphlebomyia, Ven & & \\
\hline $\begin{array}{l}\text { nepenthes, Theo. ... } \\
\text { nigeria, Theo. ... }\end{array}$ & $\ldots$ & $\begin{array}{l}\cdots \\
\cdots\end{array}$ & $\begin{array}{r}43 \\
9\end{array}$ & $\begin{array}{l}\text { Pseudohowardina, Theo. } \\
\text { pseudonigeria, Theo. ... }\end{array}$ & $\begin{array}{l}\cdots \\
\ldots\end{array}$ & $8, \ddot{9}$, \\
\hline nigeria, Theo. $\quad$... & & & 9 & pseudonigeria, Theo. ... & .. & \\
\hline
\end{tabular}




\begin{tabular}{|c|c|c|c|c|c|}
\hline \multirow[b]{2}{*}{ pseudoscutellaris, Theo. } & \multicolumn{2}{|r|}{ PAGE. } & \multicolumn{3}{|r|}{$P_{A G E}$} \\
\hline & & ... 13 & somaliensis, N.-L. & & ... 28,34 \\
\hline Pseudoskusea, Theo. $\quad$... & $\ldots$ & $\ldots$ & $\ldots$ & $\ldots$ & $\ldots 35,36$ \\
\hline Pseudotaeniorhynchus, Theo. & $\ldots$ & .. & Iuamipennis, Arrib. & ... & $\ldots \quad 25$ \\
\hline Pseudotheobaldia, Theo. & $\ldots$ & $\ldots$ & squammipenna, Theo. & ... & ... \\
\hline Pseudouranotaenia, Theo. & $\ldots$ & ... & Stegoconops, Lutz & ... & $\ldots$ \\
\hline$\ldots$ & .. & $\ldots$ & Stegomyia, & ... & ... \\
\hline$\ldots$ & ... & $\ldots \quad 20$ & us, Theo. & ... & ... \\
\hline heo. ... & ... & $, 20,21,31$ & sudanensis, I & ... & ... 16,20 \\
\hline$\ldots$ & .. & ... 28,32 & sudanensis, Theo. (Ludlowia) & & $\ldots 36,37$ \\
\hline Jewst. ... & ... & ... 24 & sugens, Wied. $\quad \ldots \quad \quad \ldots$ & ... & $\ldots 7,8,9$ \\
\hline • $\quad \ldots$ & ... & ... 28,29 & s, Theo. ... & .. & $\cdots$ \\
\hline . $\cdots$ & ... & ... 12 & us, Arrib. & .. & 24,25 \\
\hline heo. & ... & $17,23,32$ & . $\cdots \quad \ldots$ & ... & $\ldots$ \\
\hline$\cdots$ & $\ldots$ & ... & c. $\ldots$ & $\cdots$ & .. 2 \\
\hline ... & ... & ... & ... & $\cdots$ & ... 28,31 \\
\hline & $\ldots$ & $46,47,48$ & ... & .. & \\
\hline ... & $\ldots$ & $\ldots \quad 35$ & N.-L. $\quad \ldots$ & $\cdots$ & 5,27 \\
\hline . $\quad \ldots$ & ... & ... & lla, Blanch. ... & $\ldots$ & $\ldots$ \\
\hline ia, Brèthes ... & $\ldots$ & ... & p. $\quad \ldots \quad \quad \ldots$ & $\ldots$ & .. 5,28 \\
\hline$\ldots \quad \ldots$ & $\ldots$ & $\ldots$ & , Theo. ... & $\ldots$ & .. 28,31 \\
\hline & ... & ... & ites, Theo. & $\ldots$ & $\ldots \quad 2$ \\
\hline ... & $\ldots$ & $\ldots$ & $a$, Theo. & $\ldots$ & $\ldots$ \\
\hline heo. ... & ... & $\ldots$ & $s$, Theo. ... & ... & $\ldots$ \\
\hline .. $\quad \cdots$ & ... & ... & is, Theo. & $\ldots$ & $\ldots$ \\
\hline ... & .. & ... & ata, Theo. $\quad$... & $\ldots$ & ... 21,22 \\
\hline ... & ... & 48 & uniformis, Theo. (Mansonia) & & ... 26,27 \\
\hline , Theo.... & .. & ... & , Theo. (Mimomyi & & ... 44,45 \\
\hline$\ldots$ & ... & $\ldots$ & , Theo. $\quad \ldots$ & $\ldots$ & $\ldots \quad 13$ \\
\hline ... & .. & $\cdots$ & univittatus, Theo. & .. & $28,31,32$ \\
\hline ... & ... & ... & Uranotaenia, Arrib. & ... & $6,34,37$ \\
\hline ... & .. & ... & Mg. $\quad \ldots \quad \ldots$ & $\ldots$ & ... 21 \\
\hline ... & .. & 21 & i, Theo. (Danielsia) & ... & $16,18,19$ \\
\hline$\ldots$ & $\cdots$ & ... 41 & wellmani, Theo. (Stegomyia) & ... & $\ldots 9$ \\
\hline ex) & $\cdots$ & $\ldots 29,33$ & teria, Banks ... & ... & \\
\hline & $\cdots$ & $7,9,11,12$ & ri, N.-L. $\quad \cdots$ & . & ... 28,31 \\
\hline 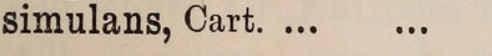 & & $15,16,18$ & zombaensis, Theo. & $\cdots$ & ... \\
\hline
\end{tabular}




\section{$2 \mathrm{BHL}$ Biodiversity Heritage Library}

Edwards, F W. 1912. "A Synopsis of the species of African Culicidae, other than Anopheles." Bulletin of entomological research 3, 1-53.

https://doi.org/10.1017/s0007485300001656.

View This Item Online: https://www.biodiversitylibrary.org/item/110755

DOI: https://doi.org/10.1017/s0007485300001656

Permalink: $\underline{\text { https://www.biodiversitylibrary.org/partpdf/98170 }}$

\section{Holding Institution}

Smithsonian Libraries

\section{Sponsored by}

Biodiversity Heritage Library

\section{Copyright \& Reuse}

Copyright Status: Public domain. The BHL considers that this work is no longer under copyright protection.

This document was created from content at the Biodiversity Heritage Library, the world's largest open access digital library for biodiversity literature and archives. Visit BHL at https://www.biodiversitylibrary.org. 